Rice University's Baker Institute

LATIN AMERICA INITIATIVE

RICE UNIVERSITY'S 20 YEARS

BAKER INSTITUTE $2 O_{1993-2013}$

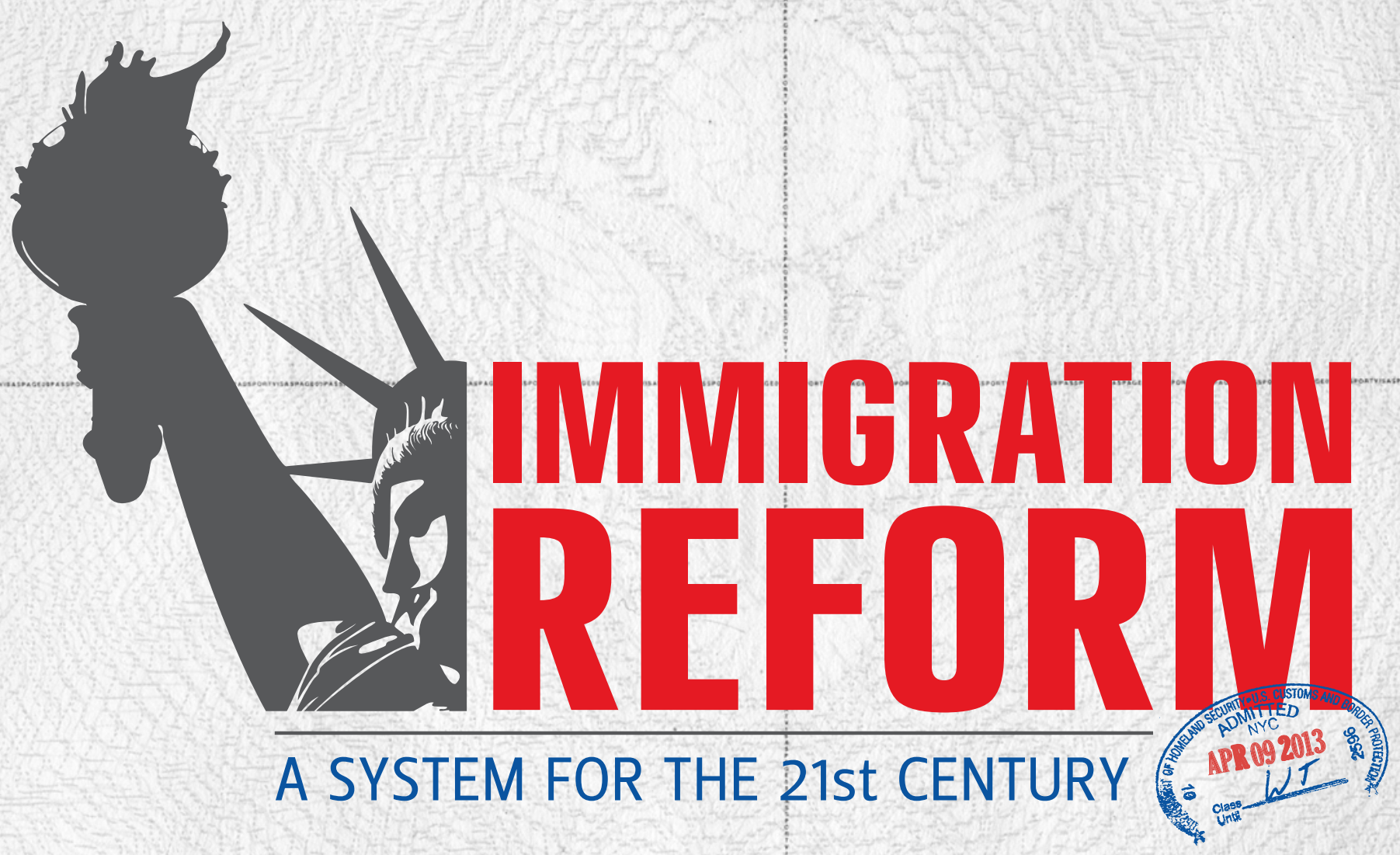

Latino Issue Priorities and Political Behavior Across U.S. Contexts

Ali A. Valenzuela, Ph.D.

Sarah K. Stein 


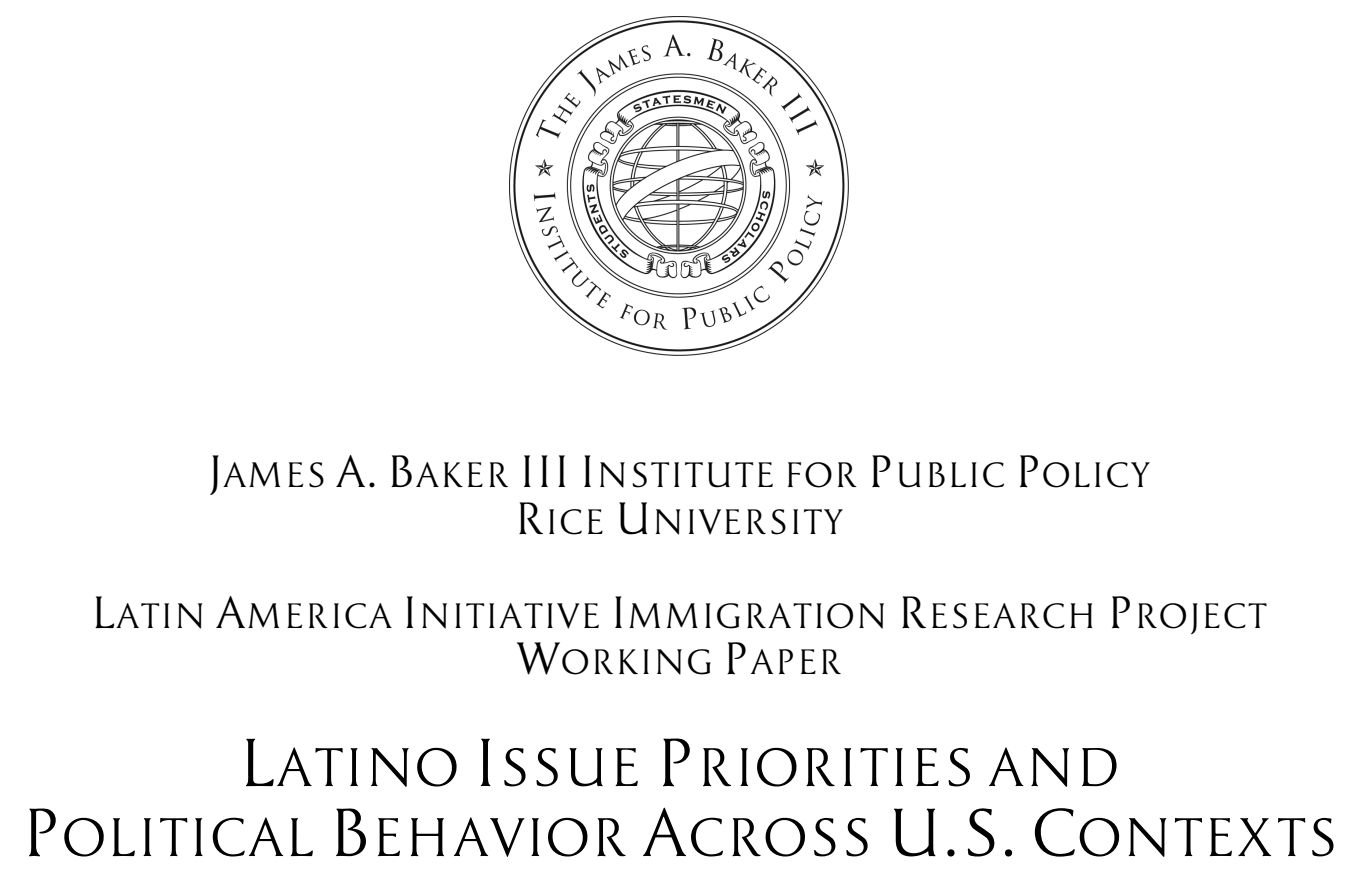

BY

\author{
Ali A. Valenzuela, Ph.D. \\ Assistant Professor, Department of Politics \\ PRINCETON UNIVERSITY \\ AND \\ SARAH K. Stein \\ ASSISTANT ECONOMIST \\ Federal Reserve Bank of New York
}

APRIL 2013 


\section{Latino Issue Priorities and Political Behavior Across U.S. Contexts}

THESE PAPERS WERE WRITTEN BY A RESEARCHER (OR RESEARCHERS) WHO PARTICIPATED IN A BAKER INSTITUTE RESEARCH PROJECT. WHEREVER FEASIBLE, THESE PAPERS ARE REVIEWED BY OUTSIDE EXPERTS BEFORE THEY ARE RELEASED. HOWEVER, THE RESEARCH AND VIEWS EXPRESSED IN THESE PAPERS ARE THOSE OF THE INDIVIDUAL RESEARCHER(S), AND DO NOT NECESSARILY REPRESENT THE VIEWS OF THE JAMES A. BAKER III INSTITUTE FOR PUBLIC POLICY.

(C) 2013 By the James A. BAKer III Institute for P UbliC POlicy Of RiCe University

THIS MATERIAL MAY BE QUOTED OR REPRODUCED WITHOUT PRIOR PERMISSION, PROVIDED APPROPRIATE CREDIT IS GIVEN TO THE AUTHOR AND THE JAMES A. BAKER III INSTITUTE FOR PUBLIC POLICY. 


\title{
Latino Issue Priorities and Political Behavior Across U.S. Contexts
}

\begin{abstract}
$^{1}$
To what extent and in which contexts is the issue of immigration salient to Latino voters and linked to their partisan attachments and voting behavior? In this study, we merge four surveys of Latino voter opinion collected in 2009, 2010, 2011 and 2012, with U.S. Census demographics and election results in order to assess how Latino issue priorities vary by individual attributes and local contextual conditions. In particular, we ask how changes in the rate of growth and size of the local Latino population interact with political competition to shape the salience of immigration among Latino voters. We argue that the process linking demographics to issue priorities is conditioned by the degree of two-party competition. In addition, we explore links between the importance that Latinos place on immigration reform and their support for the Democratic Party and President Obama in 2012. We find that immigration issue salience declines with increasing Latino population proportions, controlling for a number of individual and contextual characteristics, except prior to 2012 in electorally competitive counties where immigration issue salience is increasing with Latino population in neighborhoods. In addition, the issue of immigration is strongly predictive of Democratic Party identification and voting preference for President Obama over Governor Romney in 2012. These analyses generate insight about the impact of demographic context and the composition of local populations on the salience of immigration among Latino voters, as well as how the political environment works to politicize (or not) the issue of immigration and its connection to Latino political behavior.
\end{abstract}

\section{Introduction}

In 2008, as a first-time presidential candidate, then-Senator Barack Obama famously promised to pass comprehensive immigration reform during his first year in office. ${ }^{2}$ Once elected, President Obama instead spent the next four years dealing with a troubled economy, passing health

\footnotetext{
${ }^{1}$ The authors thank Latino Decisions for survey data from 2009 and 2012; Princeton University's Mamdouha S. Bobst Center for financial support to collect data in 2011; and Stanford University's Graduate Research Opportunity fund for financial support to collect data in 2010. Any errors are the authors' alone.

${ }^{2}$ Frank James, "Despite Obama's High Latino Support, Univision Puts Him On Hot Seat," NPR It's all Politics, 20 September 2012. Accessed 16 February 2013.
} 


\section{Latino Issue Priorities and Political Behavior Across U.S. Contexts}

insurance and finance reform laws, and dramatically increasing federal enforcement of existing laws that helped identify, apprehend and deport more undocumented immigrants than ever before. ${ }^{3}$ Other than increased enforcement, immigration reform fell largely off the presidential agenda until mid-2012, when the Department of Homeland Security (DHS) issued an administrative directive deferring prosecutorial action for two years against qualified DREAMers - otherwise law-abiding immigrants who came to the United States illegally when they were under the age of sixteen. ${ }^{4}$ For some, deferred action during a presidential election year was too little, too late. To wit, later that year at a presidential candidate forum hosted by Spanishlanguage television network Univision, President Obama was pointedly asked about his broken promise to Latino ${ }^{5}$ voters. ${ }^{6}$ The president argued that he underestimated Republican opposition to immigration reform, articulated his own continued commitment to comprehensive policy change, and contrasted his approach with that of his opponent, Governor Mitt Romney, who had argued for "self deportation," or the idea that life in the United States could be made sufficiently difficult for undocumented immigrants that they would willingly leave the country.

President Obama won reelection by a comfortable margin nationally, and by record margins among Latino voters specifically. ${ }^{7}$ In several important swing states, Latino voter turnout and support for the Democratic candidate helped ensure President Obama's reelection. ${ }^{8}$ The ensuing narrative about Latino voters, and the Democrats' advantage among them, has prompted renewed attention from Republicans about the importance of winning a larger share of the Latino electorate in future elections, in part by supporting immigration reform. ${ }^{9}$ In a similar vein, President Obama telegraphed the importance of immigration reform by discussing it in his

\footnotetext{
${ }^{3}$ John Simanski and Lesley M. Sapp, "Immigration Enforcement Actions: 2011," in Annual Report (Department of Homeland Security Office of Immigration Statistics Policy Directorate, 2012).

${ }^{4}$ Elise Foley, "Obama Administration To Stop Deporting Younger Undocumented Immigrants And Grant Work Permits," Huffington Post, 15 June 2012. Accessed 30 January 2013.

${ }^{5}$ In this essay we use the terms Latino and Hispanic interchangeably to refer to current U.S. residents who trace their ancestry to the Spanish-speaking nations of Latin America or Spain.

${ }^{6}$ James, "Despite Obama's High Latino Support, Univision Puts Him On Hot Seat."

${ }^{7}$ Julia Preston and Fernanda Santos, "A Record Latino Turnout, Solidly Backing Obama," The New York Times, 7 November 2012. Accessed 31 January 2013.

${ }^{8}$ Gary M. Segura, "The Political Calculus of Immigration Reform: What Republicans and Democrats Stand to Gain or Lose in the Upcoming Debate," in Latino Decisions (2013). Accessed 30 January 2013.

${ }^{9}$ Philip E. Wolgin and Marshall Fitz, "Top 10 Reasons Why It's Time for Immigration Reform," Center for American Progress, http:/www.americanprogress.org/issues/immigration/news/2013/01/29/50908/top-10-reasonswhy-its-time-for-immigration-reform/. Accessed 5 February 2013.
} 


\section{Latino Issue Priorities and Political Behavior Across U.S. Contexts}

second inauguration speech and detailing his preferred policy approach about a week later. ${ }^{10}$ Political pressure from Latino interests and the imperative of electoral self-preservation may finally be sufficiently aligned to produce legislative action in the House of Representatives, a major source of gridlock during President Obama's first term. And yet, despite a more favorable electoral context, it remains unclear where, precisely, the immigration issue is most salient and relevant to national politics among Latino and other voters in the American polity.

For example, while existing research shows that majorities of Latinos view immigrants positively and tend to support more liberal immigration policies, ${ }^{11}$ there is no systematic evidence about how changes in political and demographic context are associated with the salience of the immigration issue and its connection to party identification, candidate approval and vote choice. In other words, while we know that Latinos are largely supportive of immigration reform, we do not know to what extent or in which contexts this issue may have significant links to national electoral politics. In the current study, we begin to furnish evidence about this process in two steps. First, we merge four national surveys of Latino opinion collected in 2009, 2010, 2011 and 2012, with U.S. Census demographics from 2000 and 2010, and election results from 2008, in order to assess how Latino issue priorities vary by year and local context. In particular, we ask how the rate of growth and size of local Latino populations interact with political competition to shape Latino voter issue priorities on immigration. We argue that the process linking demographics to immigration issue salience is conditioned by the degree of two-party competition because of the way in which competition shapes the nature and frequency of campaign appeals on this issue.

Second, we examine linkages between immigration issue salience among Latino voters and their identification with and support for the two major parities. We conduct these analyses across time and space, generating insight about the impact of demographic context and population change on the salience of the immigration issue among Latino voters, and also how the political environment works to politicize (or not) this issue and its connection to local demographic

\footnotetext{
${ }^{10}$ Transcript of the speech may be found here: http://www.nytimes.com/2013/01/21/us/politics/obamas-secondinaugural-speech.html. Accessed 10 February 2013.

${ }^{11}$ Thomas J. Espenshade and Charles A. Calhoun, "An Analysis of Public Opinion Toward Undocumented Immigration," Population Research and Policy Review 12, no. 1 (1993); Gabriel R. Sanchez, "The role of group consciousness in Latino public opinion," Political Research Quarterly 59, no. 3 (2006).
} 


\section{Latino Issue Priorities and Political Behavior Across U.S. Contexts}

contexts. That is, our work helps clarify when and where the issue of immigration reform is made salient and politically potent among an increasingly pivotal voting group. This may yet contribute to our understanding of the process and likely outcome of a renewed push for legislative action on immigration reform.

Our findings indicate that immigration issue salience declines with increasing Latino population proportions, controlling for a number of individual characteristics. In addition, the issue of immigration is predictive of Democratic Party identification and voting preference for President Obama over Governor Romney. These analyses generate insight about the impact of demographic context and the composition of local populations on the salience of immigration among Latino voters, as well as how the political environment works to politicize (or not) the issue of immigration and its connection to Latino political behavior.

In the next section, we review existing work on immigration attitudes, both among whites and Latinos, and characterize how scholars have assessed the relationship between geographic context, variously measured, and public attitudes on immigration and immigration policy. We extend this area of inquiry by discussing the likely role of electoral context in shaping relationships between population characteristics and immigration issue salience among Latino voters by arguing that electoral context helps link the salience of the immigration issue to political outcomes such as party identification and candidate choices. After outlining our expectations, we discuss the data that we assembled for this analysis, including our definition of key variables, and the primary methods we use to analyze them. We then report key results of our analyses, discuss their implications for politics and policy, and conclude in the final section.

\section{Previous Research on Immigration, Latino Attitudes and Local Context}

Although much previous research in political science acknowledges the centrality of race and ethnicity in the history and contemporary dynamics of American politics, the bulk of this research focuses on differences in public attitudes between black and white Americans, as well 


\section{Latino Issue Priorities and Political Behavior Across U.S. Contexts}

as these group members' views of each other. ${ }^{12}$ This historical focus has often meant that other ethnic and racial groups in the U.S., especially immigrant groups, are understudied relative to their share of the population. However, as immigrant groups have grown in size, visibility and electoral influence, ${ }^{13}$ scholars have sought to understand their impact on American political behavior in three primary ways. One is to examine non-Hispanic white attitudes about immigrants and immigration policy, with work in this line of inquiry often seeking to adjudicate between economic and cultural explanations for generally negative attitudes towards immigrants and broad support for restrictive immigration policies among majority group members (whites). ${ }^{14}$ On the whole, cultural explanations that derive from white Americans' concerns about national identity and perceptions of limited immigrant assimilation typically find greater support than explanations centered on concerns about the economic costs of immigration. ${ }^{15}$

A second approach in political behavior research focused on immigration attitudes examines the opinions of immigrant group members themselves, with works that ask how individual characteristics influence support for immigration policies and attitudes towards immigrants. ${ }^{16}$

\footnotetext{
${ }^{12}$ For a review, see Vincent L. Hutchings and Nicholas A. Valentino, "The Centrality of Race in American Politics," Annual Review of Political Science 7(2004).

${ }^{13}$ Matt A. Barreto, Loren Collingwood, and Sylvia Manzano, "A New Measure of Group Influence in Presidential Elections: Assessing Latino Influence in 2008," Political Research Quarterly 63, no. 4 (2010); Gary M. Segura, "Latino Public Opinion \& Realigning the American Electorate," Daedalus 141, no. 4 (2012).

${ }^{14}$ Ted Brader, Nicholas A. Valentino, and Elizabeth Suhay, "What Triggers Public Opposition to Immigration? Anxiety, Group Cues, and Immigration Threat," American Journal of Political Science 52, no. 4 (2008); Espenshade and Calhoun, "An Analysis of Public Opinion Toward Undocumented Immigration."; Jack Citrin et al., "Public Opinion Toward Immigration Reform: The Role of Economic Motivations," Journal of Politics 59, no. 3 (1997); Adrian Pantoja, "Against the Tide? Core American Values and Attitudes Toward US Immigration Policy in the Mid1990s," Journal of Ethnic and Migration Studies 32, no. 3 (2006).

${ }^{15}$ Jack Citrin and David O. Sears, "Balancing National and Ethnic Identities: The Psychology of E Pluribus Unum," in Measuring Identity: A Guide for Social Scientists, ed. Rawi Abdelal, et al. (Cambridge: Cambridge University Press, 2009); Jack Citrin and Matthew Wright, "Defining the Circle of We: American Identity and Immigration Policy," The Forum 7, no. 3 (2009); Jens Hainmueller and Michael J. Hiscox, "Attitudes toward Highly Skilled and Low-Skilled Immigration: Evidence from a Survey Experiment," American Political Science Review 104, no. 1 (2010); Daniel J. Hopkins, Van C. Tran, and Abigail Fisher Williamson, "See No Spanish: Language, Local Context, and Attitudes toward Immigration," (Washington, D.C.: Georgetown University, 2011); Matthew Wright and Jack Citrin, "Saved by the Stars and Stripes? Images of Protest, Salience of Threat, and Immigration Attitudes," American Politics Research 39, no. 2 (2011); Peter Burns and James G. Gimpel, "Economic Insecurity, Prejudicial Stereotypes, and Public Opinion on Immigration Policy," Political Science Quarterly 115, no. 2 (2000); Thomas J. Espenshade and Katherin Hempstead, "Contemporary American Attitudes Toward U.S. Immigration," International Migration Review 30, no. 2 (1996); Espenshade and Calhoun, "An Analysis of Public Opinion Toward Undocumented Immigration."

${ }^{16}$ Regina Branton, "Latino Attitudes toward Various Areas of Public Policy: The Importance of Acculturation," Political Research Quarterly 60, no. 2 (2007); Rodolfo de la Garza et al., "Understanding Intra-Ethnic Attitude Variations: Mexican Origin Population Views of Immigration," Social Science Quarterly 72, no. 2 (1991); Benjamin R. Knoll, "¿Compañero o Extranjero? Anti-Immigrant Nativism among Latino Americans," Social Science
} 


\section{Latino Issue Priorities and Political Behavior Across U.S. Contexts}

Research that investigates specifically Hispanic attitudes about immigration is the most relevant to the current study because here we are examining Hispanic voter attention to the issue of immigration and its connection to geographic context and political attitudes. Early work in this area tested labor market competition and cultural affinity explanations using bivariate correlations and primitive regression analysis of the relationships between Hispanic attitudes and income, education, generational status and cultural attachment to Hispanic (Mexican) culture. ${ }^{17}$ Findings indicate that greater income and education, later generational status, and weaker attachments to Hispanic culture are all associated with an increased likelihood of identifying immigration as a major problem. Thus, labor market competition theory, which predicts worse attitudes among lower status and more recent immigrants who are the most in competition with new immigrants, does not explain Latino attitudes, while cultural explanations are supported.

Later work on Hispanic attitudes expands the scope of previous analyses to include respondents from multiple countries-of-origin, more robust measures of acculturation, and additional indicators of cultural affinity such as ethnic group consciousness, religious affiliation and church attendance. ${ }^{18}$ Findings largely sustain previous research: economic measures do not predict Hispanic attitudes about immigration, but measures of acculturation into American society (education, acquisition of or preference for English, and later generational status) are predictive of less support for immigration or public policies that benefit immigrants. On the other hand, ethnic attachments such as group consciousness or the perception that discrimination against Hispanics is a major problem are predictive of greater support for immigrants and beneficial immigration policies. In addition, although Hispanics generally are more supportive of

Quarterly 93, no. 4 (2012); Lawrence W. Miller, Jerry L. Polinard, and Robert D. Wrinkle, "Attitudes Toward Undocumented Workers: The Mexican American Perspective," Social Science Quarterly 65, no. 2 (1984); Lina Y. Newton, "Why Some Latinos Supported Proposition 187: Testing Economic Threat and Cultural Identity Hypotheses," Social Science Quarterly 81, no. 1 (2000); Stella M. Rouse, Betina Cutaia Wilkinson, and James C. Garand, "Divided Loyalties? Understanding Variation in Latino Attitudes Toward Immigration," Social Science Quarterly 91, no. 3 (2010); Jerry L. Polinard, Robert D. Wrinkle, and Rodolfo de la Garza, "Attitudes of Mexican Americans toward Irregular Mexian Immigration," International Migration Review 18, no. 3 (1984); Sanchez, "The role of group consciousness in Latino public opinion."

${ }^{17}$ de la Garza et al., "Understanding Intra-Ethnic Attitude Variations: Mexican Origin Population Views of Immigration."; Miller, Polinard, and Wrinkle, "Attitudes Toward Undocumented Workers: The Mexican American Perspective."; Polinard, Wrinkle, and de la Garza, "Attitudes of Mexican Americans toward Irregular Mexian Immigration."

${ }^{18}$ Branton, "Latino Attitudes toward Various Areas of Public Policy: The Importance of Acculturation."; Knoll, "¿Compañero o Extranjero? Anti-Immigrant Nativism among Latino Americans."; Rouse, Wilkinson, and Garand, "Divided Loyalties? Understanding Variation in Latino Attitudes Toward Immigration."; Sanchez, "The role of group consciousness in Latino public opinion." 


\section{Latino Issue Priorities and Political Behavior Across U.S. Contexts}

immigration than whites, ${ }^{19}$ works that examine Hispanic attitudes in greater detail provide evidence of heterogeneity in attitudes by national origin. Specifically, Mexican-origin Hispanics are more supportive of immigration and beneficial immigration policies than Puerto Ricans, Cubans or other Hispanic national origin subgroups. ${ }^{20}$

Research characterizing individual determinants of immigration attitudes provides an important foundation for understanding the politics of immigration, but it begs an obvious question: what role does immigration context, independent of individual attributes, play in the process of attitude formation? A third line of research on immigration has taken up this question by focusing on the effects of demographic contexts on attitudes of both whites and Latinos. ${ }^{21}$ Several methodological approaches have been taken in this research, with the most basic using multiple regression models to predict individual attitudes with measures of a respondent's surrounding context. ${ }^{22}$ These works operationalize context with the proportion of a respondent's county population that is Hispanic or foreign-born and Hispanic. Findings indicate that as the percent of a respondent's county population that is Hispanic increases, Latinos in these counties report more negative immigration attitudes. These results for Latinos largely parallel findings on immigration attitudes of whites in counties with larger Hispanic populations. ${ }^{23}$ Some scholars

\footnotetext{
${ }^{19}$ Espenshade and Calhoun, "An Analysis of Public Opinion Toward Undocumented Immigration."

${ }^{20}$ Branton, "Latino Attitudes toward Various Areas of Public Policy: The Importance of Acculturation."; Knoll, "¿Compañero o Extranjero? Anti-Immigrant Nativism among Latino Americans."; Rouse, Wilkinson, and Garand, "Divided Loyalties? Understanding Variation in Latino Attitudes Toward Immigration."

${ }^{21}$ Shang E. Ha, "The Consequences of Multiracial Contexts on Public Attitudes toward Immigration," Political Research Quarterly 63, no. 1 (2010); M. V. Hood III and Irwin L. Morris, "¿Amigo o Enemigo?: Context, Attitudes, and Anglo Public Opinion towards Immigration," Social Science Quarterly 78, no. 2 (1997); ——, "Give Us Your Tired, Your Poor, ... But Make Sure They Have a Green Card: The Effects of Documented and Undocumented Migrant Context on Anglo Opinion Toward Immigration," Political Behavior 20, no. 1 (1998); M. V. Hood III, Irwin L. Morris, and Kurt A. Shirkey, "'iQuedate o Vente!': Uncovering the Determinants of Hispanic Public Opinion Toward Immigration," Political Research Quarterly 50, no. 3 (1997); Daniel J. Hopkins, "Politicized Places: Explaining Where and When Immigrants Provoke Local Opposition," American Political Science Review 104, no. 1 (2010); Hopkins, Tran, and Williamson, "See No Spanish: Language, Local Context, and Attitudes toward Immigration."; Knoll, "¿Compañero o Extranjero? Anti-Immigrant Nativism among Latino Americans."; Rouse, Wilkinson, and Garand, "Divided Loyalties? Understanding Variation in Latino Attitudes Toward Immigration."; Robert M. Stein, Shirley Post, and Allison L. Rinden, "Reconciling Context and Contact Effects on Racial Attitudes," Political Research Quarterly 53, no. 2 (2000); Rene R. Rocha and Rodolfo Espino, "Segregation, Immigration, and Latino Participation in Ethnic Politics," American Politics Research 38, no. 4 (2010); Rene R. Rocha et al., "Ethnic Context and Immigration Policy Preferences Among Latinos and Anglos," Social Science Quarterly 92, no. 1 (2011).

${ }^{22}$ Knoll, "¿Compañero o Extranjero? Anti-Immigrant Nativism among Latino Americans."; Rouse, Wilkinson, and Garand, "Divided Loyalties? Understanding Variation in Latino Attitudes Toward Immigration."

${ }^{23} \mathrm{Ha}$, "The Consequences of Multiracial Contexts on Public Attitudes toward Immigration."; Hood III and Morris, "¿Amigo o Enemigo?: Context, Attitudes, and Anglo Public Opinion towards Immigration."; —_, "Give Us
} 


\section{Latino Issue Priorities and Political Behavior Across U.S. Contexts}

have complicated this basic approach by examining how other characteristics of context condition the observed relationship between attitudes and population context. For example, scholars have shown that white-Latino residential segregation, ${ }^{24}$ media attention to immigration, ${ }^{25}$ and residence in border or non-border interact with demographics to shape attitudes about immigrants and immigration policy.

This latter work on context suggests that while Hispanic population densities may have direct effects on individual attitudes through social interactions and the transmission of particular norms and attitudes that is facilitated in such environments, ${ }^{26}$ context also has important consequences for the political and informational environment of a local area. In particular, Regina P. Branton and her coauthors ${ }^{27}$ show that greater proximity to the U.S.-Mexico border generates more news media coverage and more negative news media coverage of immigration, that media coverage of immigration is greater in border than in non-border states, and that media coverage of immigration is significantly related to immigration issue salience among individual survey respondents, controlling for a variety of individual- and contextual-level characteristics. Similarly, Daniel J. Hopkins shows that negative immigration attitudes are correlated with increasing Latino population contexts, but only when the issue of immigration is a salient media topic. ${ }^{28}$ Thus, recent changes in national media attention to the issue of immigration may indicate changes in immigration issue salience among segments of the American electorate.

Your Tired, Your Poor, ... But Make Sure They Have a Green Card: The Effects of Documented and Undocumented Migrant Context on Anglo Opinion Toward Immigration."; Hopkins, "Politicized Places: Explaining Where and When Immigrants Provoke Local Opposition."

${ }^{24}$ Rene R. Rocha and Rodolfo Espino, "Racial Threat, Residential Segregation, and the Policy Attitudes of Anglos," Political Research Quarterly 62, no. 2 (2009); Rocha et al., "Ethnic Context and Immigration Policy Preferences Among Latinos and Anglos."; Rocha and Espino, "Segregation, Immigration, and Latino Participation in Ethnic Politics."

${ }^{25}$ Johanna Dunaway, Regina P. Branton, and Marisa A. Abrajano, "Agenda Setting, Public Opinion, and the Issue of Immigration Reform," Social Science Quarterly 91, no. 2 (2010); Hopkins, "Politicized Places: Explaining Where and When Immigrants Provoke Local Opposition."

${ }^{26}$ Robert Huckfeldt and John Sprague, "Networks in Context: The Social Flow of Political Information," American Political Science Review 81, no. 4 (1987); R. Robert Huckfeldt, "The Social Context of Political Change: Durability, Volatility, and Social Influence," American Political Science Review 77, no. 4 (1983).

${ }^{27}$ Regina P. Branton and Johanna Dunaway, "Spatial Proximity to the U.S.-Mexico Border and Newspaper Coverage of Immigration Issues," Political Research Quarterly 62, no. 2 (2009); Dunaway, Branton, and Abrajano, "Agenda Setting, Public Opinion, and the Issue of Immigration Reform."

${ }^{28}$ Daniel J. Hopkins, "Politicized Places: Explaining Where and When Immigrants Provoke Local Opposition," American Political Science Review 104, no. 1 (2010). 


\section{Latino Issue Priorities and Political Behavior Across U.S. Contexts}

\section{Theory and Expectations}

In part because of the close connection between immigration policy and notions of national identity and group membership, ${ }^{29}$ attitudes about immigration are shaped both by individual predispositions and the social environment in which these attitudes are formed. For Latino voters, heterogeneity within the group leads us to expect differences in the salience of immigration by nativity, national origin and party identification. Latinos born in the United States, and those further from the immigration experience temporally and generationally are expected to register less attention to immigration than foreign-born Latinos and those who have been in the United States for a shorter period of time. Similarly, because Puerto Ricans are already U.S. citizens and migration to the U.S. for these Latinos involves simply moving to the mainland, we expect them to register lower levels of attention to immigration compared to Mexican-origin and other Latino national origin groups. Cuban Latinos may also be distinct in their attention to immigration because of their unique position as the only majority-Republican Latino national origin group.

In recent years the Republican Party has, of course, espoused restrictive immigration positions that emphasize border control and other enforcement strategies while rejecting any policy proposals that include a pathway to citizenship for current undocumented immigrants. During President Obama's first term, the Republican Party helped to stymie legislative action on this issue. We expect, therefore, Republican Latinos to report lower levels of attention to immigration than Democratic and unaffiliated Latinos.

Previous research shows that local context is an important determinant of individual attitudes and political behavior, and this seems particularly true for attitudes about immigration that turn on perceptions of and exposure to the local immigrant population. But whereas existing work has examined links between Latino population contexts and immigration attitudes, no previous study considers how the electoral environment might politicize the issue of immigration in particular

\footnotetext{
${ }^{29}$ Paul M. Sniderman and Louk Hagendoorn, When Ways of Life Collide: Multiculturalism and Its Discontents in the Netherlands (Princeton: Princeton University Press, 2007); Citrin and Wright, "Defining the Circle of We: American Identity and Immigration Policy."; Citrin and Sears, "Balancing National and Ethnic Identities: The Psychology of E Pluribus Unum."
} 


\section{Latino Issue Priorities and Political Behavior Across U.S. Contexts}

contexts. On the one hand, we may believe that immigration policy, because it is under federal purview, is a national issue that generates national media coverage and little local variation in attention among the Latino electorate. If this were true, we would expect to see little or no geographic variation in the attention that Latino voters devote to the issue. There may be changes over time, but across demographic and electoral contexts, Latino issue priorities would be fairly stable under this scenario. Work by Regina P. Branton and her coauthors ${ }^{30}$ on immigration issue salience in border and non-border states, as well as Daniel J. Hopkins' work ${ }^{31}$ on white attitudes towards immigration, however, cast doubt on this perspective by showing that local attitudes about and attention to immigration vary with media coverage of the issue as well as variation in geographic context.

Does Latino attention to immigration also vary by local contextual conditions? We expect that is does, although the form of this relationship is likely to be more complicated for Latinos than it is for whites because of heterogeneity within the Latino population discussed previously. We consider three specific complications of context in our analysis below: the local electoral environment; measurement of Latino population contexts; and the geographic unit of analysis. First, we focus on presidential two-party competitiveness as our measure of the electoral environment and expect competitiveness to moderate relationships between population contexts and immigration issue salience because of the nature of campaign activity in competitive areas. ${ }^{32}$ In locales with competitive elections and sizable Latino populations, appeals to and about immigration should be more frequent, increasing the salience of this issue among Latino voters compared to those in uncompetitive areas with similar Latino populations. Spanish language advertising and coverage of elections are also expected to be greater in competitive areas, and research shows that Spanish language coverage of immigration is more frequent and more favorable than English language coverage. ${ }^{33}$ Thus, we expect any effects of population contexts on immigration issue salience to be conditioned by electoral competitiveness, with any such

\footnotetext{
${ }^{30}$ Branton and Dunaway, "Spatial Proximity to the U.S.-Mexico Border and Newspaper Coverage of Immigration Issues."; Dunaway, Branton, and Abrajano, "Agenda Setting, Public Opinion, and the Issue of Immigration Reform."

${ }^{31}$ CITE

${ }^{32}$ Ali A. Valenzuela, "Identity in Context: How Neighborhoods, Churches and Campaigns Shape Latino Unity" (Ph.D. diss, Stanford University, 2011).

${ }^{33}$ Regina Branton and Johanna Dunaway, "English- and Spanish-Language Media Coverage of Immigration: A Comparative Analysis," Social Science Quarterly 89, no. 4 (2008).
} 


\section{Latino Issue Priorities and Political Behavior Across U.S. Contexts}

relationships accentuated in competitive areas and muted in safe ones.

Previous research has also shown that whites and Latinos react similarly when population context is measured as the overall Latino population, ${ }^{34}$ while later work shows that Latinos are more discerning and react differently when population context is examined separately as nativeand foreign-born Latino group sizes. ${ }^{35}$ We also expect Latino voters to place a different emphasis on immigration depending on how population context is measured. Given our expectations about national origin differences in Latino voter attention to the issue of immigration, we believe that differences in national origin population contexts will also have variable effects on attention to immigration among Latino voters. Namely, larger Mexican-origin populations will be associated with greater attention to immigration among Latinos who live in these contexts, while larger Puerto Rican- and Cuban-origin populations will generate less attention, all else equal.

In terms of the geographic unit of analysis, previous research suggests that neighborhood-level context is the most relevant for measuring one's social environment and, particularly, exposure to immigrants and other group members. On the other hand, if immigration concerns cue notions of national membership and group identity, larger aggregations such as counties or states may be more relevant. For example, one might identify more strongly as a member of a state, metropolitan area or city before one identifies as a resident of a particular neighborhood or Census tract. Under this latter scenario, direct contact or exposure to the Latino or immigrant population is not necessary; instead, mere perceptions of the city or metropolitan demographic context may be sufficient to activate the salience of immigration as a political issue. Another consideration is one of mathematics: neighborhoods are more numerous, and more heterogeneous, than counties or states so there is more statistical power to detect an effect of neighborhood-level context. As such, we expect neighborhoods, defined here as U.S. Census tracts, to be the contexts most relevant to immigration issue salience for Latino voters.

Finally, our expectations about individual- and contextual-level determinants of immigration

\footnotetext{
${ }^{34}$ Hood III and Morris, "¿Amigo o Enemigo?: Context, Attitudes, and Anglo Public Opinion towards Immigration."; Hood III, Morris, and Shirkey, "'iQuedate o Vente!': Uncovering the Determinants of Hispanic Public Opinion Toward Immigration."

${ }^{35}$ Rocha and Espino, "Segregation, Immigration, and Latino Participation in Ethnic Politics."; Rocha et al., "Ethnic Context and Immigration Policy Preferences Among Latinos and Anglos."
} 


\section{Latino Issue Priorities and Political Behavior Across U.S. Contexts}

issue salience among Latino voters does not tell us anything about how identifying this issue as a top concern may be related to important political outcomes such as party identification and vote choice. To assess this link, we propose using a multiple regression framework that allows us to assess the impact of issue salience while simultaneously controlling for other factors that previous research has shown are related to party identification and vote choice. We expect that Latino voters who identify immigration as a top issue will be positively and significantly more likely to both identify with the Democratic Party and to express a vote preference for President Obama over Governor Romney, compared to Latinos who identify other issues as their top concern.

\section{Data and Methods}

To assess our expectations, we rely on four cross-sectional surveys of Latino voter opinion collected in each of the four years of President Obama's first term in office (2009-2012). ${ }^{36}$ All four surveys interviewed a nationally representative sample of Latino registered voters contacted by telephone using fully bilingual professional callers. The exact states included in each sample vary somewhat from survey to survey, but all surveys include states with the largest Latino populations, and the 2012 survey includes respondents from all fifty states. ${ }^{37}$ Strictly speaking, the four surveys are not a time series because each sample was independently drawn and respondents were not re-interviewed in subsequent surveys. Any apparent temporal changes in issue salience, party identification or other attitudes, therefore, should not be interpreted as conclusive evidence of shifts in Latino attitudes because some of the shift could be due to changes in the composition of the Latino electorate. Nonetheless, all surveys were conducted using the same polling firm and survey mode and similar sampling frames over a relatively short period of time, providing some confidence that observed shifts over time represent meaningful changes in opinion. Further, differences across Latino subgroups within each survey are the main quantities of interest that we compare.

Because the surveys only include Latino registered voters, sample characteristics are somewhat

\footnotetext{
${ }^{36}$ The 2009 survey data were collected in May; 2010 and 2011 data were collected in October; and 2012 data were collected in November just before the presidential election.

${ }^{37}$ Please see the Appendix for sample characteristics.
} 


\section{Latino Issue Priorities and Political Behavior Across U.S. Contexts}

skewed from the general population of Latinos in the U.S. (see the Appendix). Particularly, the Latino registered voter samples examined here are on average older, later in generational status, wealthier and more educated than the general Latino population. However, since the main interest in the current study is to investigate sources of immigration issue salience and its relationship to political outcomes such as party identification and voting behavior, relying on Latino registered voter samples is appropriate. In addition, because the samples are drawn from registered voter lists, each respondent includes complete address information that allows us to locate respondents at their precise residential location using Geographic Information Systems (GIS). Using this location information, we merge U.S. Census and electoral contest results data to each respondent in order to characterize and measure their surrounding contexts.

We use Census data from 2000 and 2010 to create demographic and socioeconomic indicators of each respondent's context at multiple levels: state, county and neighborhood. We define neighborhoods using Census-designated tracts, which are designed to be homogenous with respect to population characteristics, economic status and living conditions. ${ }^{38}$ Such homogeneity is a close approximation to neighborhood divisions and ensures that tract-level measures of context are reflective of the demographic environment in which respondents live. Counties are substantially larger geographic units that typically include hundreds of Census tracts and may be useful for characterizing the limits of an individual's surrounding demographic and electoral environment. We use county-level presidential results from the 2008 election as a measure of the electoral environment, calculating the percentage-point vote margin between the top two candidates (President Obama and Senator McCain) such that smaller values indicate a more competitive contest. We use this measure to define competitive counties as those with a vote margin of less than 10 percentage points and safe counties as those with a vote margin of 10 percentage points or greater.

To examine immigration issue salience, we use questions that ask respondents about their issue priorities, which capture the salience of immigration compared to other policy areas. Unfortunately, variation in the question wording across the four surveys limits some comparisons. Nonetheless, although year-to-year comparisons are somewhat tenuous, within-

\footnotetext{
${ }^{38}$ U.S. Census Bureau, http://www.census.gov/geo/www/cen_tract.html.
} 


\section{Latino Issue Priorities and Political Behavior Across U.S. Contexts}

year comparisons across issues are reliable. Additionally, in three of the four surveys (2009, $2010,2011)$, the question wording is similar, while in the last two $(2011,2012)$ there is an alternative wording of the issue priority question. For three years we can characterize changes in responses over time, and again for the last two years. ${ }^{39}$ In what follow, we pool data from 20092011 and again for 2011-2012 in order to conduct separate analyses for these two periods.

Each of the surveys also contain relevant information about a respondent's age, gender, nativity (born in the U.S., Puerto Rico or elsewhere), country of origin (we code respondents into those from Mexico, Puerto Rico, Cuba and Spain, comparing those groups with the remaining), generational status (the later surveys only asked about a respondent's parents' birthplace, limiting us to identifying first, second and third generation Latinos), partisanship (Democratic, Republican and unaffiliated), education, income, survey language preference (English or Spanish), and region in the United States. We also create a variable for non-border and border states (including California, Arizona, New Mexico, Texas, Louisiana, Mississippi and Florida). All of these variables serve as important controls in our multiple regression analyses and some (nativity, national origin, partisanship and border state residence) are likely to be important for distinguishing attention to the immigration issue and its relationship to key political outcomes.

We report results of our analyses below, starting with bivariate relationships between individual characteristics of Latino voters and immigration issue salience-that is, the proportion that identify immigration as a top issue concern - across survey years. We then proceed to bivariate correlations between immigration issue salience and contextual characteristics of respondent counties and neighborhoods, examining these relationships among all Latinos in our samples and then by party identification because of expected differences in how context may politicize the issue of immigration for Democratic, Republican and unaffiliated Latinos. Contexts that

\footnotetext{
${ }^{39}$ In 2009 , the issue priority question asked Latino voters what they "think is the most important issue that President Obama and the new Congress should address during 2009," while in 2010 the question asked, "if the election for U.S. Congress were being held today, what general issues would be most important to you in deciding who to vote for?" The change in wording shifted the emphasis of the question from general concerns to specific concerns about vote choice. In 2011, the issue priority question again focused attention on voter behavior: "when it comes to deciding if you will vote, and who to vote for, what issues are the most important in how you evaluate the candidates and your decision to vote?" Also in 2011, the survey asked a second issue priority question that focused attention on issues of concern to Latinos: "Generally speaking, what are the most important issues facing the Latino community that you think Congress and the President should address?" Similarly in 2012: "Thinking about the 2012 election, what are the most important issues facing the (Hispanic/Latino) community that our politicians should address?"
} 


\section{Latino Issue Priorities and Political Behavior Across U.S. Contexts}

demonstrate a significant correlation with immigration issue salience indicate that Latino voters in these environments are substantially more or less likely (depending on the sign of the correlation) to identify this issue as a top concern as values on the contextual measure increase. Because the salience of immigration is likely to vary significantly by individual attributes, we also pursue multiple regression analysis of identifying immigration as a top issue, allowing us to account for potential confounding relationships simultaneously.

Finally, we examine how the issue of immigration, compared to other issues, is related to party identification and vote choice in 2012 , key political outcomes for understanding the Latino vote in American politics. To do this, we regress indicator variables for Democratic Party identification and preference for President Obama over Governor Romney separately on issue priorities, individual attributes and contextual characteristics of Latino voters. Estimates from these regressions reveal the probability that comparably situated Latino voters, who select immigration reform as a top issue, identify as Democrats and support President Obama in selfreported vote choice. In other words, the models allow us to examine the relationship between these outcomes and issue priorities while simultaneously controlling for socioeconomic and other factors such as national origin and nativity that we hypothesize are systematically related to which issues Latino voters select as their top concern. ${ }^{40}$

\section{Results}

The first thing to note from Figures 1 and 2 is that the change in wording of the issue priority question, from one about the most important issue for a respondent's vote (Figure 1), to one about the most important issue facing the Latino community (Figure 2), appears to have substantially increased the proportion of Latino voters who identify immigration as their top concern. The "top issue for vote" question asked in 2009-2011 generated between 11 and 16\% of Latino respondents identifying immigration as a top concern (Figure 1), while the "top issue facing the Latino community" question asked in 2011-2012 generated between 24 and 31\% of Latinos identifying immigration as a top concern (Figure 2). We can be confident that it was the change in wording that caused some of the increases apparent in Figure 2 because the 2011

\footnotetext{
${ }^{40}$ All models use logit regression functions and are run with national probability weights and robust standard errors.
} 


\section{Latino Issue Priorities and Political Behavior Across U.S. Contexts}

survey included both questions, and there is a 19 percentage-point difference from one question wording to the other in that year (compare 12\% of all Latinos in 2011 in Figure 1, to 31\% of all Latinos in 2011 in Figure 2). Similar comparisons between Figures 1 and 2, focusing on 2011, can be made for various Latino subgroups, and in every instance the salience of immigration is greater among Latino voters responding to the question that asked about the top issue facing the Latino community. The average difference is about 17 percentage-points, with the smallest differences between the two question wordings among Puerto Ricans and Cubans. For many Latino voters, asking about the most important issue facing their community serves as a kind of cue about immigration policy. These results suggest that Latino voters recognize immigration as an issue of special concern for the Latino community. (See Figure 1 at end of paper.)

Nonetheless, and as expected, Puerto Rican and Cuban Latinos register among the lowest attention to immigration when asked about their top issue for voting, with both groups maxing out in 2010 at 10\% and 15\%, respectively (Figure 1). In fact, Puerto Ricans report among the lowest levels of attention to immigration regardless of how the issue priority question is worded (7-10\% in 2009-2011 and only 16\% in 2011-2012 for the Latino community version of the question). This is in contrast to Cuban Latinos, who register higher levels of attention to immigration when asked about their top concern for the Latino community in 2011 (26\%), although this drops again in 2012 to only 18\% (see Figure 2 at end of paper).

U.S.-born and Republican Latinos are also less likely than other Latinos to say immigration is the top issue for their vote (Figure 1), maxing out at 10\% and 12\%, respectively, in 2010. Interestingly, the proportion of these two groups identifying immigration as a top issue for the Latino community in 2011 (28\% and 32\%, respectively) is high and not meaningfully different from the overall Latino community. In 2012, however, U.S.-born and Republican Latinos revert to lower levels of attention to immigration (22\% and $16 \%$, respectively), figures that are similar to Puerto Ricans in that year (16\%) and lower than the overall Latino population (24\%). This decline in the how important immigration is among native and Republican Latinos may be driven by the 2012 presidential campaign and the increased salience of other issues.

As expected, Mexican-origin and foreign-born Latinos are among the most likely to identify 


\section{Latino Issue Priorities and Political Behavior Across U.S. Contexts}

immigration as a top issue, both for their vote and for the Latino community. This is particularly the case when comparing foreign-born to U.S.-born Latinos in 2009 and 2010, with smaller differences in 2011 for both versions of the issue priority question. There are no meaningful differences in immigration issue salience between foreign- and U.S.-born Latinos by November 2012. Again, the presidential election may have played a role in politicizing the issue of immigration sufficiently to increase its salience among both U.S.-born and foreign-born Latinos and making these two groups indistinguishable. On the other hand, Mexican-origin Latinos continued to be more likely to identify immigration as a top issue compared to Puerto Ricans in 2009 and 2010, and again in 2011 and 2012.

Considering next the relationship between immigration issue salience among Latino voters and the geographic contexts in which these voters live, Table 1 shows Pearson's $r$ correlation coefficients for identifying immigration as a top issue in 2009-2011 (panel A) and identifying immigration as a top issue in 2011-2012 (panel B). Both county- and neighborhood (tract)-level measures of context are pairwise correlated with identifying immigration as the top issue, first for all Latinos in the samples and then separately for Democrats, Republicans and unaffiliated Latino voters. Although several measures of context are significantly correlated with immigration issue salience $(\mathrm{p}<0.05)$, most are quite modest associations.

Nonetheless, not all measures of context correlate with identifying immigration as a top issue, and those that do increase in associational strength for Republican and unaffiliated Latinos, but not for Democrats. Among Democratic Latinos, there are no significant correlations between context and immigration issue salience in 2009-2011 (panel A), and virtually no differences in the size of the associations in 2011-2012 (panel B) compared to the full sample. These patterns of results suggest two inferences. First, Republican and unaffiliated Latino voters are more likely than Democratic Latinos to be influenced by their surrounding contexts in terms of attention to the issue of immigration. Second, measures of context examined here are much more consistently related to immigration issue salience when Latino voters are asked about the most important issue facing the Latino community rather than when asked about their most important issue more generally. (See panel B in Table 1 at end of paper.) 


\section{Latino Issue Priorities and Political Behavior Across U.S. Contexts}

Substantively, the results in Table 1 show some intriguing relationships. First, examining only panel A, the size of the Mexican-origin Latino population at either level of geography (county or neighborhood) is positively associated with immigration issue salience, particularly among Republican and unaffiliated Latinos (but not among Democratic Latinos). Puerto Rican-origin Latino population proportion is negatively related to immigration issue salience among the full sample and especially so among Republican Latinos, the latter finding consistent at both countyand tract-levels of analysis. For unaffiliated Latinos, however, results for the size of the Puerto Rican-origin Latino population diverge across levels of context: increasing Puerto Rican population in one's county appears to increase attention to immigration, while larger Puerto Rican populations in one's neighborhood (tract) appears to depress attention to immigration.

Fast forward to 2011-2012, looking at results in panel B of Table 1 for the most important issue facing the Latino community, the size of the overall Latino population is negatively correlated with attention to immigration. This negative correlation between increasing Latino population size and immigration issue salience is present among the full sample and separately among Democrats and Republicans. The similarly negative correlations between percentage-point change in the size of the overall Latino population (between 2000 and 2010) and immigration issue salience suggests that the importance of immigration will decline with larger Latino populations in either counties or neighborhoods, at least among Democratic Latino voters who are asked about the most important issue facing the Latino community. It may be the case that Democratic Latino voters perceive other issues as more important for the Latino community as their demographic surroundings become increasingly Latino.

The bivariate correlations reported in Table 1 should be interpreted with caution, however, because greater national-origin population proportions, at both geographic levels (counties and neighborhoods), will also increase the likelihood that any given respondent taken from these contexts hails from the same nation-of-origin as the surrounding population. To determine whether individual- or contextual-level characteristics are more predictive of immigration issue salience while controlling for the impact of each factor simultaneously, we use multiple regression to predict immigration issue salience with individual Latino voter characteristics (Table 2), then combined with county-level measures of context (Table 3), and then separately 


\section{Latino Issue Priorities and Political Behavior Across U.S. Contexts}

combining individual characteristics with tract-level measures (Table 4).

Several expected results are apparent in Table 2, which presents two models that pool data from (1) 2009-2011 and then from (2) 2011-2012. ${ }^{41}$ First, in 2009-2011, foreign-born (compared to U.S.-born) and second generation (compared to third and later generation) Latino voters are significantly more likely to identify immigration as their top issue, findings that remain largely unchanged in 2011-2012 except for a decline in the size of the coefficients for nativity and generation. Second, Puerto Rican (compared to Mexican-origin) Latinos are somewhat less likely to report attention to immigration in both time periods. Third, in 2009-2011, income is a significant determinant of immigration issue salience, with greater income associated with declining attention to immigration, a relationship that disappears by 2011-2012. Interestingly, preference for completing the survey interview in English is significantly related to declining attention to immigration in 2009-2011 but not in 2011-2012. Conversely, increasing age is associated with more attention to immigration in 2011-2012 but not in 2009-2011. These models also include a count for the number of years that Obama was president in order to capture temporal changes in issue salience, and this measure shows that immigration issue salience declined in 2012 compared to 2011. (See Table 2 at end of paper).

Table 3 presents results of four models that include county-level contextual measures and all of the individual-level measures from the previous analysis as control variables. ${ }^{42}$ Models (1) and (2) show truncated results from 2009-2011, and models (3) and (4) show truncated results from 2011-2012. Results here confirm two findings from the bivariate correlations in Table 1. First, greater Latino population density in U.S. counties is significantly related to a decline in immigration issue salience, and this is true for both periods (and thus for both versions of the issue priorities question). Across the range of county-level percent Latino population, the probability of identifying immigration as a top issue declines by about 22 percentage points in 2009-2011 and also by about 22 percentage points in 2011-2012. The size of these relationships is large, slightly larger than individual-level Republican (versus Democratic), U.S.-born (versus

\footnotetext{
${ }^{41}$ Model (1) shows results of the "most important issue for vote" question asked in 2009-2011, while model (2) shows results of the "most important issue for the Latino community" question asked in 2011-2012. See fn. 40 for details about exact question wording.

${ }^{42}$ Results for individual-level variables are substantively identical to those reported in Table 2 but not shown for space consideration; they are available upon request.
} 


\section{Latino Issue Priorities and Political Behavior Across U.S. Contexts}

foreign-born) and Puerto Rican-origin (versus Mexican-origin) declines in the probability of identifying immigration as a top issue, combined. (See Table 3 at end of paper).

Figure 4 graphically depicts these changes in probability of identifying immigration as a top issue across the range of percent Latino population in U.S. counties. The predicted probabilities are derived from models (2) and (4) in Table 3, with all other individual- and contextual-level variables held constant at their mean values. Panels (A) and (B) show declines in probability across percent Latino population in 2009-2011 and 2011-2012, respectively, while panels (C) and (D) show changes in the probability of identifying the economy or jobs as a top issue in these periods using the same model specifications as those for the issue of immigration. As can be seen by comparing (A) and (C), and (B) and (D), increasing county-level Hispanic population proportions are associated with a decline in immigration issue salience and a concomitant rise in economic or job issue salience. For Latino voters, these two issues were the most important for their vote or the Latino community, and their relationship to the size of the Hispanic population is inverted. (See Figure 4 at end of paper.)

Second, the larger the share of the Latino population that originates from Puerto Rico, the less attention paid to immigration in 2011-2012 among Latino voters in these county contexts, controlling for nation-of-origin and other individual characteristics (models [3] and [4] of Table 3). ${ }^{43}$ In the same models, Puerto Ricans - that is, individual national ancestry from Puerto Rico-are also significantly less likely to identify immigration as a top issue for the Latino community $(\beta=-0.53, p<0.05$; results not shown). Comparing the size of these individual- and county-level relationships in model 4 , Puerto Ricans are about 8 percentage points less likely than Mexican-origin Latinos to identify immigration as a top issue, while moving from the least Puerto Rican population contexts to the most Puerto Rican decreases the likelihood of Latino voters in these contexts identifying immigration as a top issue by about 15 percentage points. Country-of-origin is important for understanding the salience of immigration among Latino voters, but county-level population context plays an arguably more substantial role.

\footnotetext{
${ }^{43}$ There is a consistently negative but not significant relationship between \% Puerto Rican and immigration issue salience in 2009-2011. The significant (one-tailed, $\mathrm{p}<0.05$ ) and negative coefficients for $\%$ Puerto Rican in models (3) and (4) are driven entirely by respondents in 2012 (results not shown).
} 


\section{Latino Issue Priorities and Political Behavior Across U.S. Contexts}

Interestingly, and contrary to expectations as well as the bivariate results in Table 1, neighborhood-level measures of context are either weakly or not at all predictive of immigration issue salience when controlling for other neighborhood- and individual-level factors concurrently (Table 4). Percent Latino in a respondent's neighborhood (tract) is consistently negative but only marginally significant in 2011-2012 (models [3] and [4]). This is in contrast to the percent Latino in a respondent's county, which is consistently significant and negatively related to immigration issue salience. However, as in the county-level models, percent Puerto Rican in one's neighborhood is negative and significant in 2011-2012 using a directional hypothesis test (onetailed, $\mathrm{p}<0.05)$, producing a decline of about 14 percentage points in the probability of identifying immigration as a top issue across the range of neighborhood-level Puerto Rican population proportions. (See Table 4 at end of paper.)

There is one important exception to the weak results for neighborhood-level contextual measures shown in Table 4, and that is the interaction term for percent Latino and competitive counties in 2009-2011. The positive and significant relationship of this interaction variable indicates that in

electorally competitive counties, where the margin of victory between President Obama and Senator McCain in 2008 was less than 10 percentage points, increasing Latino population share is associated with greater attention to the issue of immigration. Specifically, Latino voters in competitive counties, across the range of Latino population share at the neighborhood level, are 8.3 percentage points more likely to identify immigration as a top issue. This finding partially confirms our hypothesis that the salience of immigration among Latino voters is conditioned by the degree of two-party competition and the size of the local Latino population. It may be the case that greater political competition over Latino voters leads to increased discussion and appeals about immigration in such contexts.

Figure 5 depicts graphically the changes in probability in immigration issue salience derived from the interaction term in model (2) of Table 4. The left panel shows probability plots for competitive (lighter points, positively sloping) and safe (darker points, negatively sloping) counties separately, while the right panel shows changes in probabilities between competitive and safe counties across the range of neighborhood-level percent Latino population. At about 38$40 \%$ Latino in local neighborhoods, the issue of immigration is equally salient in competitive or 


\section{Latino Issue Priorities and Political Behavior Across U.S. Contexts}

safe counties; above this population threshold, immigration is more salient with greater electoral competition, while below this threshold immigration is more salient where elections are safe. (See Figure 5 at end of paper.)

Ultimately, identifying individual- and contextual-level determinants of immigration issue salience does not tell us whether and to what extent this issue is related to key political outcomes such as party identification and candidate choice among the Latino electorate. Previous analyses of immigration issue salience, using the same data from 2009-2011 as those analyzed here, provide evidence of a relationship between identifying immigration as a top issue and temporal changes in Congressional approval and the likelihood of turning out to vote among Latino voters. ${ }^{44}$ These previous findings demonstrate that Latinos who identify immigration as a top issue (compared to Latinos identifying other issues) are, over this time period, significantly less likely to approve of the job Congress is doing, and more likely to say that they are certain to cast a ballot. Results were somewhat mixed for party identification and presidential approval but nonetheless suggest a weakening of the otherwise positive relationship between the immigration issue and Democratic identification and presidential approval. The question now is whether the issue of immigration was sufficiently salient to be predictive of party identification and vote choice in the 2012 presidential election.

To provide evidence for this proposition, Table 5 shows truncated models of Democratic Party identification and support for President Obama regressed on each of the issue variables (other issues is the excluded comparison category) as well as the full set of individual- and contextuallevel variables analyzed previously. ${ }^{45}$ This provides a gauge of whether the issue of immigration, compared to other issues, is predictive of Democratic identification and preference for President Obama over Governor Romney. Table 5 also shows results separately for all Latino voters as well as for those who reside in border and non-border states since the issue of immigration has elsewhere been shown to be more salient in border states. ${ }^{46}$

\footnotetext{
${ }^{44}$ Ali A. Valenzuela, "Latino Issue Priorities Linked to Presidential, Congressional Approval and Certainty of Voting," in Latino Decisions (2012).

${ }^{45}$ Party identification is not included in either set of models.

${ }^{46}$ Dunaway, Branton, and Abrajano, "Agenda Setting, Public Opinion, and the Issue of Immigration Reform." We also ran the full model with an interaction term for border state and immigration issue salience with substantively identical results; the interaction term is positive and significant, one-tailed $(\beta=0.46, \mathrm{p}<0.05)$.
} 


\section{Latino Issue Priorities and Political Behavior Across U.S. Contexts}

Although this analysis cannot rule out reverse causality whereby Democratic Party identification and support for President Obama increases the salience of immigration, the results indicate that this issue is significantly and substantially related to both political outcomes, and this is especially true in border states. For Latino voters, identifying immigration as a top issue for the Latino community increased the probability of Democratic Party identification by about 12 percentage points and the probability of voting for Obama by 10 percentage points, figures that increase to 15 percentage points and 13 percentage points, respectively, in border states. In nonborder states, there is no apparent relationship between identifying immigration as a top issue and either Democratic Party identification or presidential voting preference. ${ }^{47}$

Figure 3 graphically depicts a story similar to that found in Table 5. The plots show the salience of each issue in Table 5 conditional on vote choice in 2012 (only) for all Latinos (top graph) and then separately for Latinos who live in border and non-border states (bottom two graphs). For each issue, two points are drawn representing the percentage identifying that issue who also indicated vote intentions for President Obama (blue circles) or Governor Romney (red triangles). The distance between the two points for each issue shows visually how far apart supporters of the two candidates are on the issues, and their location on the plot show how important they are. For example, the top graph for all Latino voters in 2012 shows that over 50\% of Romney supporters identify the economy as a top issue in 2012 , compared to less than $40 \%$ of Obama supporters. This distance between supporters of the two candidates, on the issue of the economy, is greater than the distance between supporters of the two candidates on any other issue, including immigration. Further, more supporters of both candidates identified the economy as a top issue than identified other issues (shown by the position of the economy points and line). The distance between supporters of the two candidates, on the issue of immigration, is slightly larger among Latinos in border states than among the full sample, while the gap disappears completely among Latinos who live outside of border states. Immigration overall is about as important to Latino voters in border and non-border states, but this issue divides the Latino electorate only in

\footnotetext{
${ }^{47}$ The models in Table 5 analyze pooled data from 2011 and 2012; we re-specified each model separately for 2011 and 2012 and find that the results for the entire sample and for border states are entirely driven by respondents in 2012. This may be due in part to the substantially larger sample size for 2012, but it may also reflect effects of a hard-fought presidential campaign in which immigration reform was an important campaign issue.
} 


\section{Latino Issue Priorities and Political Behavior Across U.S. Contexts}

border states. (See Figure 3 at end of paper.)

\section{Robustness Checks}

In order to validate the results of our analysis, we performed several robustness checks. First, we tested the validity of our measurement of competitiveness by using three alternate definitions. In the original analysis, degree of electoral competitiveness was defined as a binary variable, based on the 2008 presidential vote margin. Counties registering a vote margin of less than 10 percentage points were considered competitive, while those with larger margins were considered safe. Using this definition, we found that at the neighborhood level there was a significant and positive relationship between immigration issue salience and the interaction term for percent Latino and competitive counties in 2009-2011. We subjected this finding to additional scrutiny using three alterative definitions of competitiveness: (1) a vote margin less than 5 percentage points, (2) a vote margin less than 15 percentage points, and (3) a continuous variable equivalent to the vote margin.

For all three alternative definitions of competitiveness, the interaction term for neighborhoodlevel percent Latino and competitive counties in 2009-2011 remains at least marginally significant (at the 10\% level), confirming the robustness of this result. In addition, the continuous measure of competitiveness interacted with neighborhood Latino population proportion generates a larger positive coefficient (significant at the 5\%) level and the continuous measure of competitiveness is itself a marginally significant predictor of immigration issue salience, suggestive that degree of two-party competition works to make this issue of immigration salient in any demographic context. At the county level, the relationship between immigration issue salience and the interaction of competitiveness, when measured continuously, and Latino population proportion is again positive and significant for 2009-2011. In the early part of President Obama's administration, greater Latino population size-whether measured at the neighborhood or county levels - appears to interact dynamically with two-party competition to produce increased issue salience among Latino voters. The other relationships identified in the original analysis remain largely unchanged under all definitions of the competitiveness variable. 


\section{Latino Issue Priorities and Political Behavior Across U.S. Contexts}

Second, we assessed whether our definition of border states, which included states bordering Mexico and states bordering the Gulf of Mexico, was too broad. Our two alternative definitions are more restrictive, with the first consisting of states sharing a border with Mexico and Florida (due to its large Cuban-American population) and the second consisting of only states with a physical border with Mexico. Using these alternative definitions, we find our results to be largely unchanged. At the county level, the relationship between percent Latino and immigration issue salience remains negative and significant for all definitions of the border states. Similarly, the percent Puerto Rican remains marginally significant in 2011-2012. At the neighborhood level, percent Latino remains consistently negative and is once again marginally significant in 20112012. Furthermore, the interaction term between percent Latino and county competitiveness remains positive and significant in 2009-2011. There is one point of difference, however: the relationship between percent Puerto Rican and immigration issue salience loses significance in 2011-2012 for the border state definition that includes only states with a physical border with Mexico. This result is somewhat unsurprising because of the relatively high concentration of Puerto Ricans living in Florida.

\section{Discussion of Results}

We have shown that the issue of immigration is not equally important for all segments of the Latino electorate. For predictable Latino subgroups, this issue is simply less important for garnering their vote than other issues such as the economy or education. Puerto Rican, Cuban, native-born and later generation Latinos all tend to report less attention to the issue of immigration throughout President Obama's first term. Somewhat contrary to previous research on this topic, increasing income is related to declining attention to immigration, suggestive that lower income Latino voters are paying the most attention to this issue. English-speaking Latinos are also less likely to say immigration is their top concern, compared to Spanish speakers, a result that was expected and re-confirms Spanish-speaking Latinos' interest in this issue.

We also provide compelling evidence that local contextual characteristics are significantly related to immigration issue salience. Against our expectations and somewhat counterintuitively, Latino voters who live in areas with increasingly large Latino population proportions report less attention to the issue of immigration. Conversely, these same Latino voters report 


\section{Latino Issue Priorities and Political Behavior Across U.S. Contexts}

more attention to the economy or jobs. It appears that as Latino voters' county population context becomes increasingly Latino, there will be less concern that immigration, over other issues, is most important for politicians to address. This may stem from feelings of greater comfort or social acceptance in high Latino population contexts stemming, perhaps, from friendlier local immigration policies or more supportive attitudes towards immigrants present in such contexts. We cannot test these propositions with the current data but leave these hypotheses for future research.

In addition to assessing the individual and contextual determinants of immigration issue salience among Latino voters, we also assess how this issue, compared to other issues, is related to Latino voters' Democratic Party identification and vote preference for President Obama over Governor Romney in the 2012 election. We provide strong evidence that the salience of immigration is a significant and positive predictor of Democratic affiliation and voting for Obama, relationships that are robust to controls for a wide variety of individual- and contextual-level characteristics. Interestingly, these relationships are only significant and of meaningful size in border states, where the issue of immigration is more germane to daily life than it is in other states. Appeals to Latino voters in these states, on the issue of immigration, may be particularly effective at increasing the salience of immigration and connecting it to key political outcomes.

\section{Policy Implications}

Results from the foregoing analyses strongly suggest that local contextual conditions interact with individual attributes to shape the attention that Latino voters devote to immigration and, in turn, how this issue is related to Latino party affiliation and vote preferences. At a basic level, the results here give lie to the notion of a unified Latino voting bloc on this issue. On the contrary, there are important and predictable differences in attention to immigration across a number of relevant subgroupings in the Latino community. Higher income, non-Mexican and later generation Latinos all report less attention to immigration, so appeals about the importance of immigration reform should be sensitive to these potentially diverging interests. 


\section{Latino Issue Priorities and Political Behavior Across U.S. Contexts}

Moreover, contrary to our own a priori expectations, immigration as a political issue is not more relevant in counties and neighborhoods with larger Latino populations. In fact, the data indicate that the opposite is true: Latino attention to immigration declines with the size of the Latino population, while attention to the economy and jobs increases. These results obtain despite controlling for median household income, so it is not simply that heavily Latino contexts are also more economically distressed and therefore more in need of jobs than less heavily Latino contexts. Immigration reform is certainly important to the Latino community, but so is economic development and job creation, an issue over which Latino voters were more likely to support Governor Romney than President Obama. If part of the rationale for immigration reform is its potential positive impact on jobs and the economy, such appeals should be communicated loudly and repeatedly to the broader Latino electorate. Any potential aspects of immigration reform policy that could have a positive economic impact on local Latino communities should be vigorously pursued and communicated as part of the goals for reform. This would help bring attention to immigration reform in places where Latinos have their attention tuned to other issues and help solidify support across the heterogeneous Latino community.

Finally, the analysis of Latino party affiliation and vote choice strongly suggests that the relevance of immigration salience for these two important political outcomes is driven primarily by Latinos who reside in border states, variously defined. Immigration as a political issue is not significantly more salient in border states compared to non-border states, but conditional on Latino voters identifying this issue as the most important, it is only in border states where it appears to be significantly related to Democratic Party affiliation and support for President Obama. This is perhaps an unsurprising result, but it again suggests the importance of tailored messaging on the issue of immigration and recognition that pursuit of reform will have differential impacts depending on Latino voters' place of residence. Immigration reform has the potential to have its largest impact on Latino voters who reside in border states, both because of their likely greater personal connection to undocumented immigrations but also, as we have shown, because of the relationships between this issue and party affiliation and vote choice. 


\section{Latino Issue Priorities and Political Behavior Across U.S. Contexts}

\section{Appendix}

Table A. Sample Characteristics

\begin{tabular}{|c|c|c|c|c|}
\hline & May 2009 & October 2010 & October 2011 & November 2012 \\
\hline Age (mean) & 52 years & 54 years & 46 years & 46 years \\
\hline Education (mode) & Some college & Some college & Some college & Some college \\
\hline Income (mode) & $\$ 20-40,000$ & $\$ 20-40,000$ & $\$ 40-80,000$ & $\$ 40-80,000$ \\
\hline Female gender & $51 \%$ & $51 \%$ & $52 \%$ & $52 \%$ \\
\hline Foreign born & $50 \%$ & $48 \%$ & $50 \%$ & $52 \%$ \\
\hline 2nd generation & $26 \%$ & $28 \%$ & $30 \%$ & $28 \%$ \\
\hline $3 r d+$ generation & $24 \%$ & $22 \%$ & $19 \%$ & $20 \%$ \\
\hline Mexican nat'l origin & $52 \%$ & $56 \%$ & $54 \%$ & $55 \%$ \\
\hline Puerto Rican nat'l orig & $9 \%$ & $11 \%$ & $9 \%$ & $9 \%$ \\
\hline Cuban nat'l origin & $6 \%$ & $6 \%$ & $4 \%$ & $6 \%$ \\
\hline Democrat & $71 \%$ & $66 \%$ & $69 \%$ & $71 \%$ \\
\hline Voted / will vote & $86 \%$ & $77 \%$ & $82 \%$ & $100 \%$ \\
\hline Presidential approval & $81 \%$ & $65 \%$ & $66 \%$ & $69 \% *$ \\
\hline Congressional approval & $68 \%$ & $40 \%$ & $27 \%$ & N/A \\
\hline Avg. \% Latino (county) & $39 \%$ & $38 \%$ & $39 \%$ & $36 \%$ \\
\hline Avg. \% White non-Hisp. (county) & $42 \%$ & $42 \%$ & $42 \%$ & $45 \%$ \\
\hline Avg. \% Mexican-origin (county) & $62 \%$ & $61 \%$ & $60 \%$ & $61 \%$ \\
\hline Avg. \% P.R.-origin (county) & $10 \%$ & $11 \%$ & $10 \%$ & $10 \%$ \\
\hline Avg. \% Cuban-origin (county) & $4 \%$ & $4 \%$ & $5 \%$ & $4 \%$ \\
\hline Avg. \% Latino (tract) & $51 \%$ & $50 \%$ & $49 \%$ & $45 \%$ \\
\hline Avg. \% White non-Hisp. (tract) & $34 \%$ & $34 \%$ & $34 \%$ & $38 \%$ \\
\hline Avg. \% Mexican-origin (tract) & $62 \%$ & $61 \%$ & $59 \%$ & $60 \%$ \\
\hline Avg. \% P.R.-origin (tract) & $11 \%$ & $11 \%$ & $11 \%$ & $10 \%$ \\
\hline Avg. \% Cuban-origin (tract) & $4 \%$ & $5 \%$ & $5 \%$ & $5 \%$ \\
\hline Avg. \$ median income (county) & $\$ 49,970$ & $\$ 50,307$ & $\$ 51,167$ & $\$ 50,989$ \\
\hline Avg. \% electoral margin (county) & $27 \%$ & $28 \%$ & $27 \%$ & $24 \%$ \\
\hline Observations & 595 & 593 & 982 & 5592 \\
\hline
\end{tabular}




\section{Latino Issue Priorities and Political Behavior Across U.S. Contexts}

States (N)

$\begin{array}{ll}\text { AZ (25), CA } & \text { AZ (33), CA } \\ \text { (170), CO (16), } & (204), \text { CO (10), } \\ \text { CT (6), FL (63), } & \text { CT (5), FL (68), } \\ \text { IL (23), MA (3), } & \text { GA (3), IL (2), } \\ \text { MD (9), MI (4), } & \text { MA (9), MD (2), } \\ \text { MN (2), NC (3), } & \text { MI (8), NC (4), } \\ \text { NJ (19), NM (14), } & \text { NJ (14), NM (32), } \\ \text { NV (14), NY (48), } & \text { NV (7), NY (50), } \\ \text { OH (6), PA (14), } & \text { OH (7), PA (12), } \\ \text { TX (148), VA (2), } & \text { TX (108), WA } \\ \text { WA (5), WI (1) } & (10), \text { WI (5) }\end{array}$

AZ (35), CA

(299), CO (37),

CT (21), FL

(163), GA (2), IL

(49), MA (12),

AL (5), AR (3), AZ

(401), CA (800), CO

(401), CT (11), FL

(801), GA (14), IA (6),

ID (6), IL (41), IN

(10), KS (10), KY (3),

LA (16), MA (400),

MD (4), MI (10),

MD (1), MI (15), MN

NC (6), NJ (20),

(1), MO (3), MS (2),

NC (404), NE (4), NH

NM (54), NV

(21), NY (53), OH

(1), NJ (52), NM

(394), NV (400), NY

(111), OH (400), OK

(3), PA (7), TX

(3), OR (7), PA (16),

(140), VA (16),

RI (5), SC (5), TN (3),

WA (16), WI (14)

TX (401), UT (11),

VA (400), WA (14),

WI (11)

*Approximation based on \% planning to vote for Barack Obama. 


\section{Latino Issue Priorities and Political Behavior Across U.S. Contexts}

\section{References}

Barreto, Matt A., Loren Collingwood, and Sylvia Manzano. "A New Measure of Group Influence in Presidential Elections: Assessing Latino Influence in 2008." Political Research Quarterly 63, no. 4 (2010): 908-21.

Brader, Ted, Nicholas A. Valentino, and Elizabeth Suhay. "What Triggers Public Opposition to Immigration? Anxiety, Group Cues, and Immigration Threat." American Journal of Political Science 52, no. 4 (2008): 959-78.

Branton, Regina. "Latino Attitudes toward Various Areas of Public Policy: The Importance of Acculturation." Political Research Quarterly 60, no. 2 (2007): 293-303.

Branton, Regina, and Johanna Dunaway. "English- and Spanish-Language Media Coverage of Immigration: A Comparative Analysis." Social Science Quarterly 89, no. 4 (2008): 100622.

Branton, Regina P., and Johanna Dunaway. "Spatial Proximity to the U.S.-Mexico Border and Newspaper Coverage of Immigration Issues." Political Research Quarterly 62, no. 2 (2009): 289-302.

Burns, Peter, and James G. Gimpel. "Economic Insecurity, Prejudicial Stereotypes, and Public Opinion on Immigration Policy." Political Science Quarterly 115, no. 2 (2000): 201-25.

Citrin, Jack, Donald P. Green, Christopher Muste, and Cara Wong. "Public Opinion toward Immigration Reform: The Role of Economic Motivations." Journal of Politics 59, no. 3 (1997): 858-81.

Citrin, Jack, and David O. Sears. "Balancing National and Ethnic Identities: The Psychology of E Pluribus Unum." In Measuring Identity: A Guide for Social Scientists, edited by Rawi Abdelal, Yoshiko M. Herrera, Alastair Iain Johnston and Rose McDermott. Cambridge: Cambridge University Press, 2009.

Citrin, Jack, and Matthew Wright. "Defining the Circle of We: American Identity and Immigration Policy." The Forum 7, no. 3 (2009).

de la Garza, Rodolfo, Jerry L. Polinard, Robert D. Wrinkle, and Tomás Longoria Jr. "Understanding Intra-Ethnic Attitude Variations: Mexican Origin Population Views of Immigration." Social Science Quarterly 72, no. 2 (1991): 379-87. 


\section{Latino Issue Priorities and Political Behavior Across U.S. Contexts}

Dunaway, Johanna, Regina P. Branton, and Marisa A. Abrajano. "Agenda Setting, Public Opinion, and the Issue of Immigration Reform." Social Science Quarterly 91, no. 2 (2010): 359-78.

Espenshade, Thomas J., and Charles A. Calhoun. "An Analysis of Public Opinion toward Undocumented Immigration." Population Research and Policy Review 12, no. 1 (1993): 189-224.

Espenshade, Thomas J., and Katherin Hempstead. "Contemporary American Attitudes toward U.S. Immigration." International Migration Review 30, no. 2 (1996): 535-70.

Foley, Elise. "Obama Administration to Stop Deporting Younger Undocumented Immigrants and Grant Work Permits." Huffington Post, 15 June 2012.

Ha, Shang E. "The Consequences of Multiracial Contexts on Public Attitudes toward Immigration." Political Research Quarterly 63, no. 1 (2010): 29-42.

Hainmueller, Jens, and Michael J. Hiscox. "Attitudes toward Highly Skilled and Low-Skilled Immigration: Evidence from a Survey Experiment." American Political Science Review 104, no. 1 (2010): 61-84.

Hood III, M. V., and Irwin L. Morris. "¿Amigo O Enemigo?: Context, Attitudes, and Anglo Public Opinion Towards Immigration." Social Science Quarterly 78, no. 2 (1997): 30923.

—. "Give Us Your Tired, Your Poor, ... But Make Sure They Have a Green Card: The Effects of Documented and Undocumented Migrant Context on Anglo Opinion toward Immigration." Political Behavior 20, no. 1 (1998): 1-15.

Hood III, M. V., Irwin L. Morris, and Kurt A. Shirkey. "'iQuedate O Vente!': Uncovering the Determinants of Hispanic Public Opinion toward Immigration." Political Research Quarterly 50, no. 3 (1997): 627-47.

Hopkins, Daniel J. "Politicized Places: Explaining Where and When Immigrants Provoke Local Opposition." American Political Science Review 104, no. 1 (2010): 40-60.

Hopkins, Daniel J., Van C. Tran, and Abigail Fisher Williamson. "See No Spanish: Language, Local Context, and Attitudes toward Immigration." Washington, D.C.: Georgetown University, 2011.

Huckfeldt, R. Robert. "The Social Context of Political Change: Durability, Volatility, and Social Influence." American Political Science Review 77, no. 4 (1983): 929-44. 


\section{Latino Issue Priorities and Political Behavior Across U.S. Contexts}

Huckfeldt, Robert, and John Sprague. "Networks in Context: The Social Flow of Political Information." American Political Science Review 81, no. 4 (1987): 1197-216.

Hutchings, Vincent L., and Nicholas A. Valentino. "The Centrality of Race in American Politics." Annual Review of Political Science 7 (2004): 383-408.

James, Frank. "Despite Obama's High Latino Support, Univision Puts Him on Hot Seat." NPR It's all Politics, 20 September 2012.

Knoll, Benjamin R. "¿Compañero O Extranjero? Anti-Immigrant Nativism among Latino Americans." Social Science Quarterly 93, no. 4 (2012): 911-31.

Miller, Lawrence W., Jerry L. Polinard, and Robert D. Wrinkle. "Attitudes toward Undocumented Workers: The Mexican American Perspective." Social Science Quarterly 65, no. 2 (1984): 482-94.

Newton, Lina Y. "Why Some Latinos Supported Proposition 187: Testing Economic Threat and Cultural Identity Hypotheses." Social Science Quarterly 81, no. 1 (2000): 180-94.

Pantoja, Adrian. "Against the Tide? Core American Values and Attitudes toward Us Immigration Policy in the Mid-1990s." Journal of Ethnic and Migration Studies 32, no. 3 (2006): 51531.

Polinard, Jerry L., Robert D. Wrinkle, and Rodolfo de la Garza. "Attitudes of Mexican Americans toward Irregular Mexian Immigration." International Migration Review 18, no. 3 (1984): 782-99.

Preston, Julia, and Fernanda Santos. "A Record Latino Turnout, Solidly Backing Obama." The New York Times, 7 November 2012.

Rocha, Rene R., and Rodolfo Espino. "Racial Threat, Residential Segregation, and the Policy Attitudes of Anglos." Political Research Quarterly 62, no. 2 (2009): 415-26.

—. "Segregation, Immigration, and Latino Participation in Ethnic Politics." American Politics Research 38, no. 4 (2010): 614-35.

Rocha, Rene R., Thomas Longoria, Robert D. Wrinkle, Benjamin R. Knoll, Jerry L. Polinard, and James Wenzel. "Ethnic Context and Immigration Policy Preferences among Latinos and Anglos." Social Science Quarterly 92, no. 1 (2011): 1-18.

Rouse, Stella M., Betina Cutaia Wilkinson, and James C. Garand. "Divided Loyalties? Understanding Variation in Latino Attitudes toward Immigration." Social Science Quarterly 91, no. 3 (2010): 856-82. 


\section{Latino Issue Priorities and Political Behavior Across U.S. Contexts}

Sanchez, Gabriel R. "The Role of Group Consciousness in Latino Public Opinion." Political Research Quarterly 59, no. 3 (2006): 435.

Segura, Gary M. "Latino Public Opinion \& Realigning the American Electorate." Daedalus 141, no. 4 (2012): 98-113.

—_. "The Political Calculus of Immigration Reform: What Republicans and Democrats Stand to Gain or Lose in the Upcoming Debate." In Latino Decisions, 2013.

Simanski, John, and Lesley M. Sapp. "Immigration Enforcement Actions: 2011." In Annual Report: Department of Homeland Security Office of Immigration Statistics Policy Directorate, 2012.

Sniderman, Paul M., and Louk Hagendoorn. When Ways of Life Collide: Multiculturalism and Its Discontents in the Netherlands. Princeton: Princeton University Press, 2007.

Stein, Robert M., Shirley Post, and Allison L. Rinden. "Reconciling Context and Contact Effects on Racial Attitudes." Political Research Quarterly 53, no. 2 (2000): 285-303.

Valenzuela, Ali A. "Identity in Context: How Neighborhoods, Churches and Campaigns Shape Latino Unity." Ph.D. diss, Stanford University, 2011.

_ . "Latino Issue Priorities Linked to Presidential, Congressional Approval and Certainty of Voting." In Latino Decisions, 2012.

Wolgin, Philip E., and Marshall Fitz. "Top 10 Reasons Why It's Time for Immigration Reform." Center for American Progress, http://www.americanprogress.org/issues/immigration/news/2013/01/29/50908/top-10reasons-why-its-time-for-immigration-reform/.

Wright, Matthew, and Jack Citrin. "Saved by the Stars and Stripes? Images of Protest, Salience of Threat, and Immigration Attitudes." American Politics Research 39, no. 2 (2011): 32343. 
Figure 1. Latino Immigration Issue Salience in 2009-2011

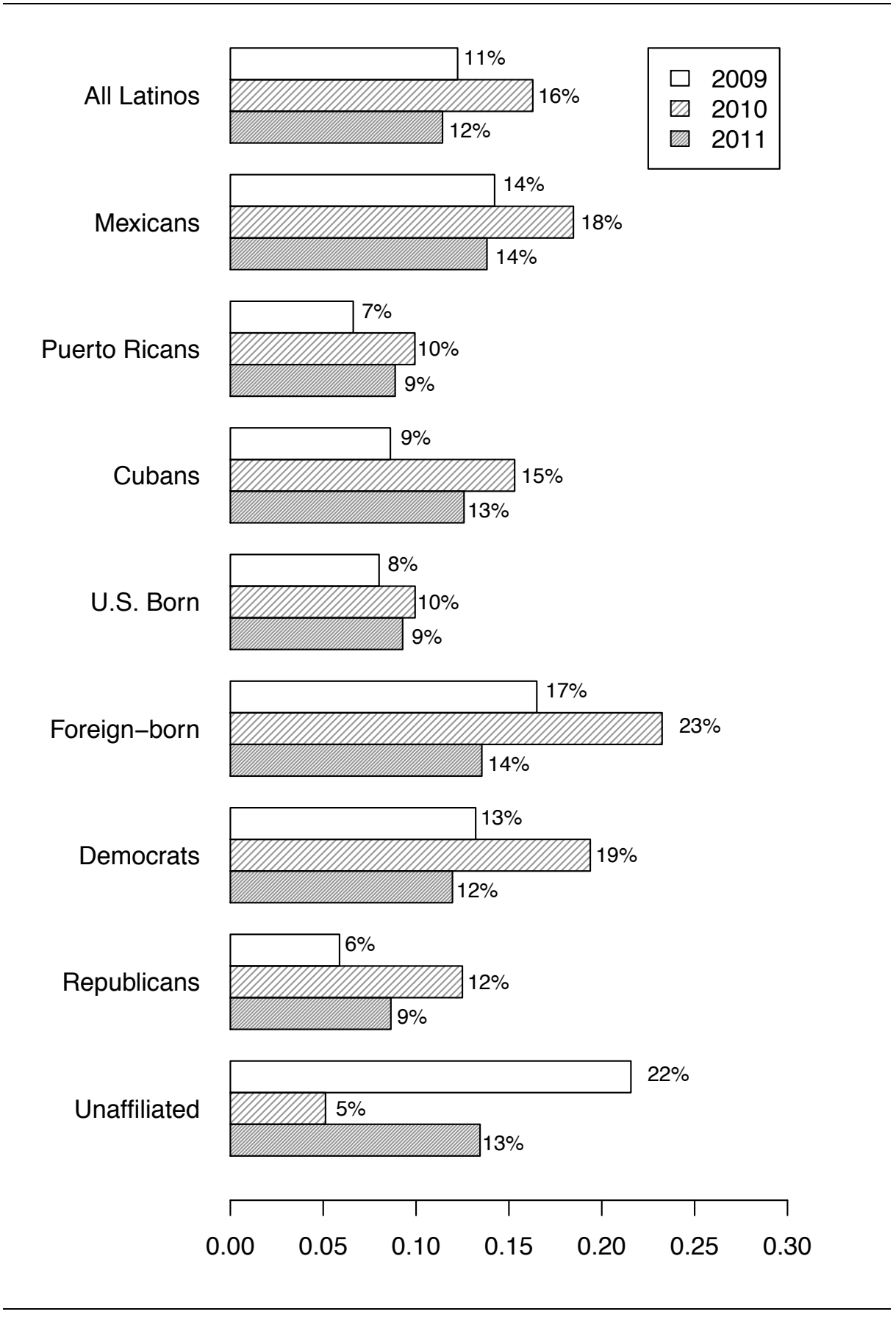


Figure 2. Latino Immigration Issue Salience in 2011-2012

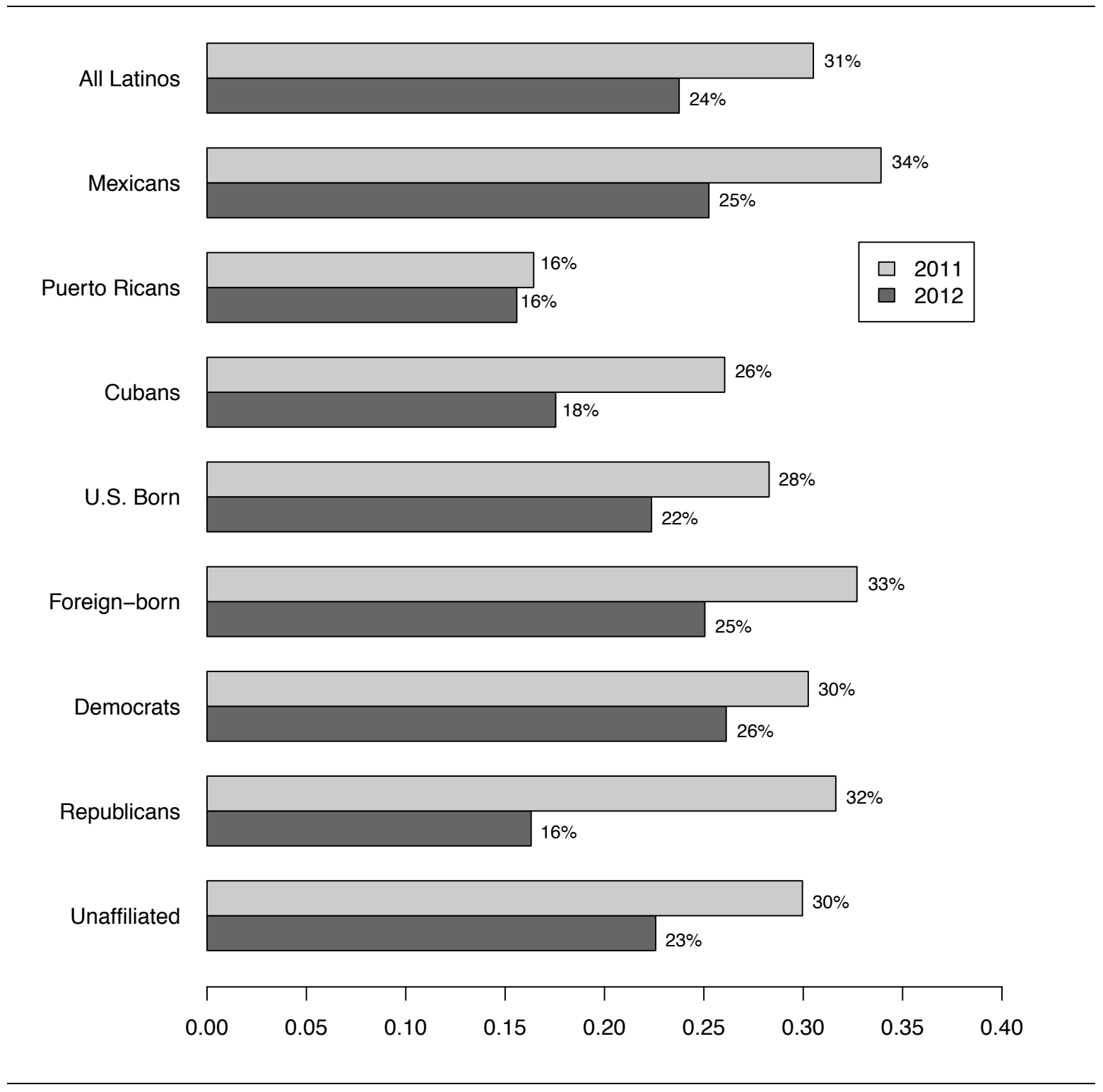


Latino Issue Priorities and Political Behavior Across U.S. Contexts

Figure 3. Issue Salience Conditional on Vote Choice in 2012

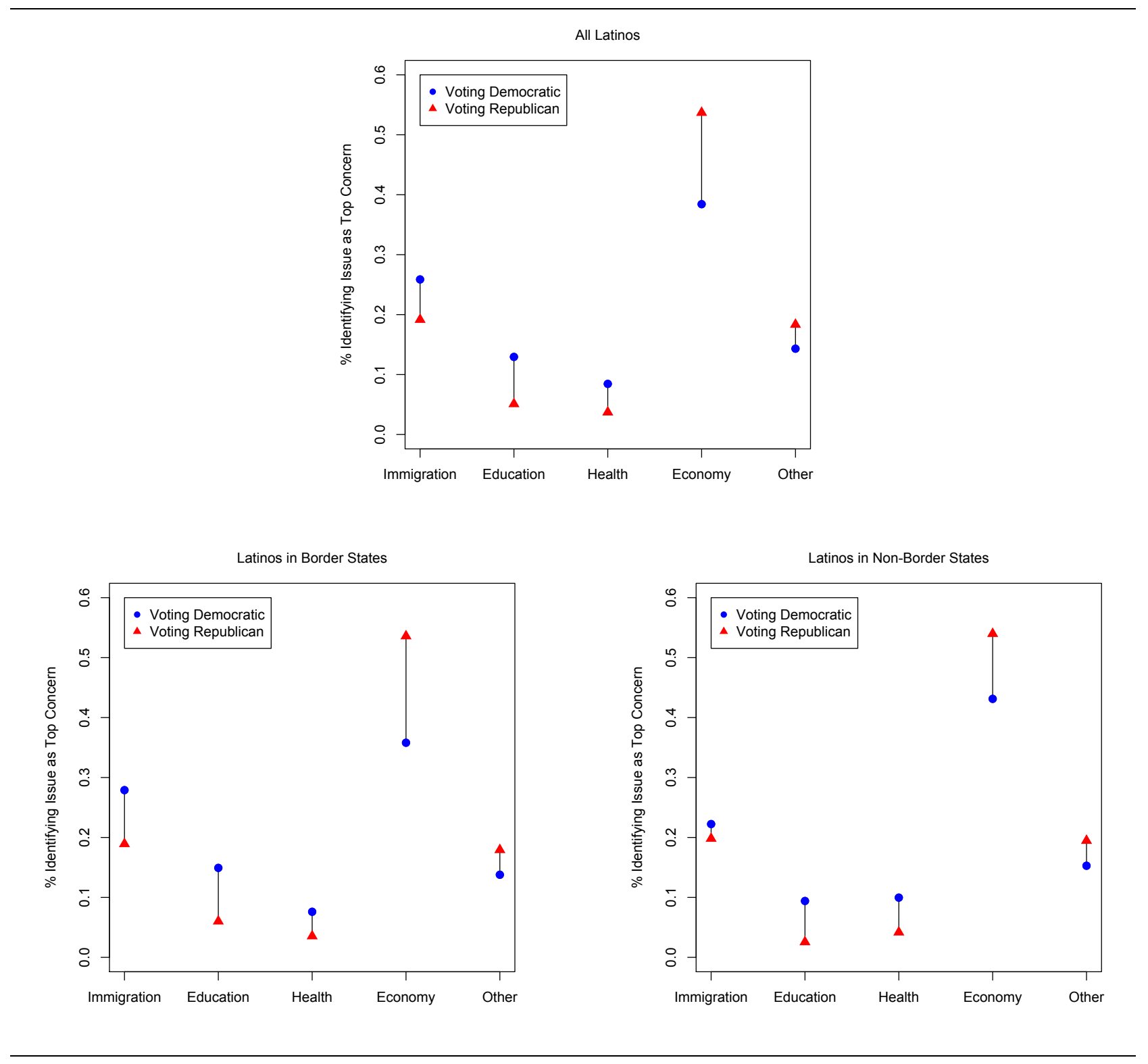




\section{Latino Issue Priorities and Political Behavior Across U.S. Contexts}

Figure 4. Predicted Probabilities of Issue Salience by County \% Latino Population

(A) 2009-2011 Immigration Salience

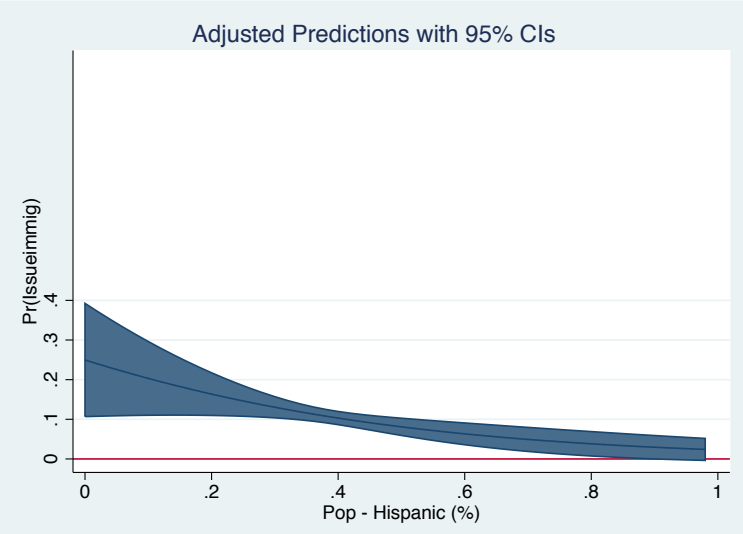

(C) 2009-2011 Economy / Jobs Salience

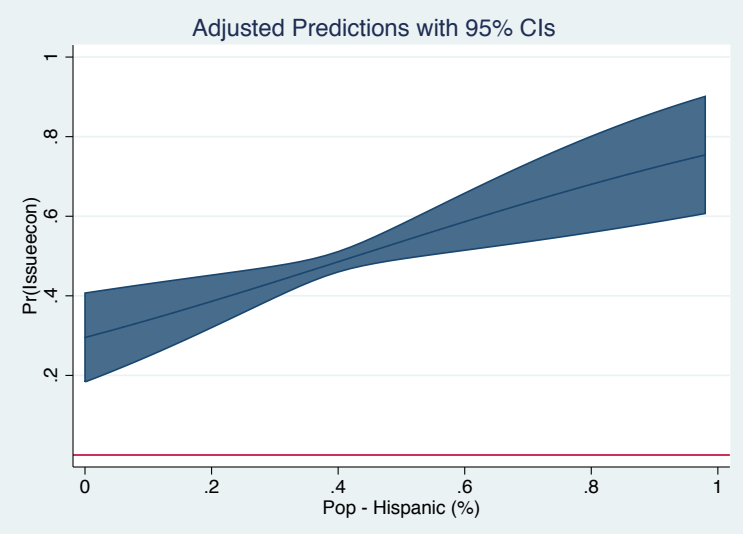

(B) 2011-2012 Immigration Salience

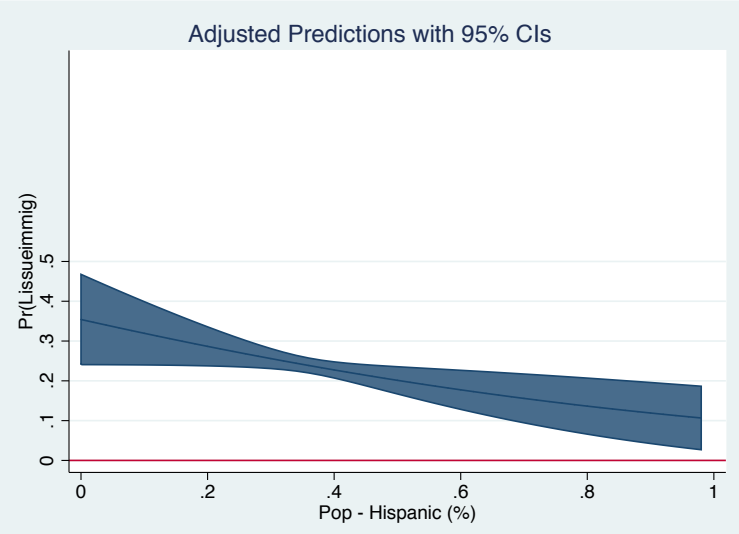

(D) 2011-2012 Economy / Jobs Salience

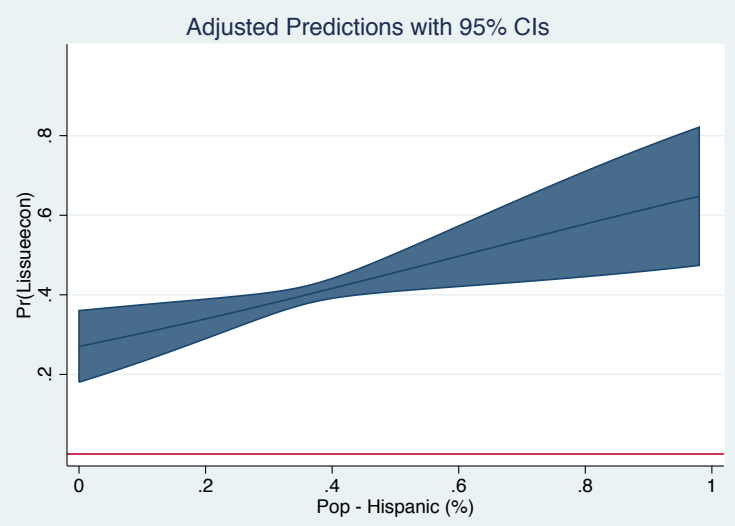


Latino Issue Priorities and Political Behavior Across U.S. Contexts

Figure 5. Predicted Probabilities and Changes in Probability of Immigration Issue Salience by Neighborhood \% Latino Population and Competitive or Safe Counties
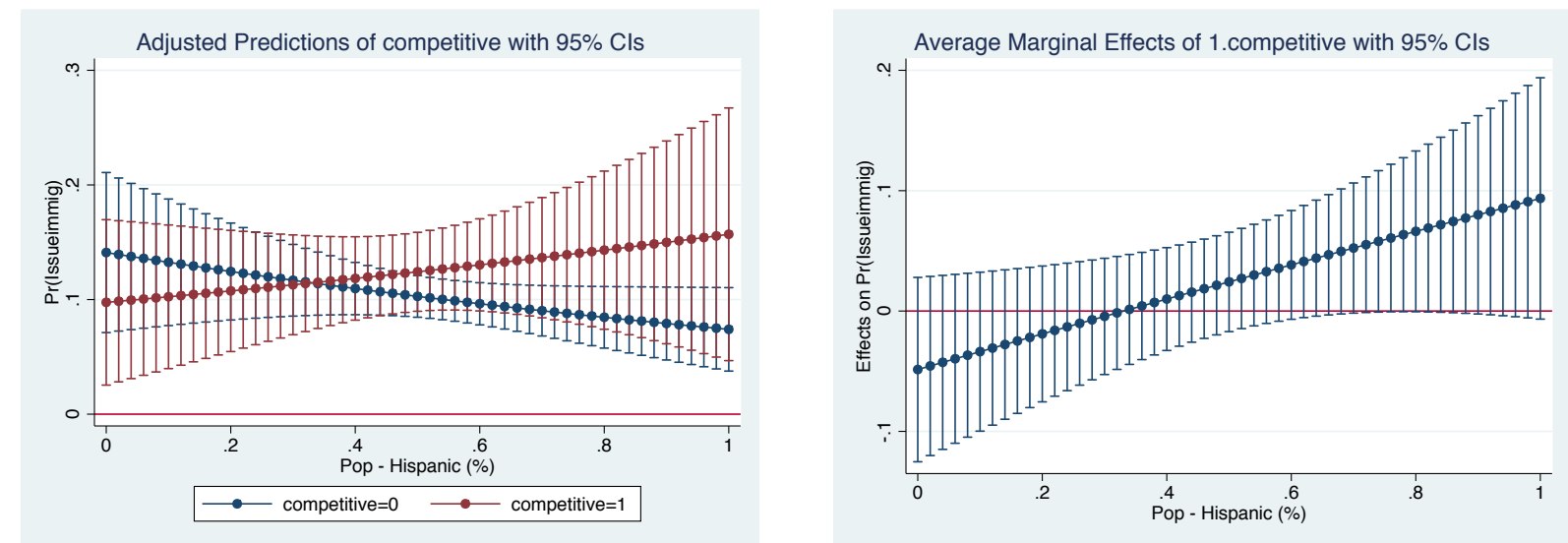


\section{Latino Issue Priorities and Political Behavior Across U.S. Contexts}

Table 1. Correlations between Immigration Issue Salience and Geographic Contexts

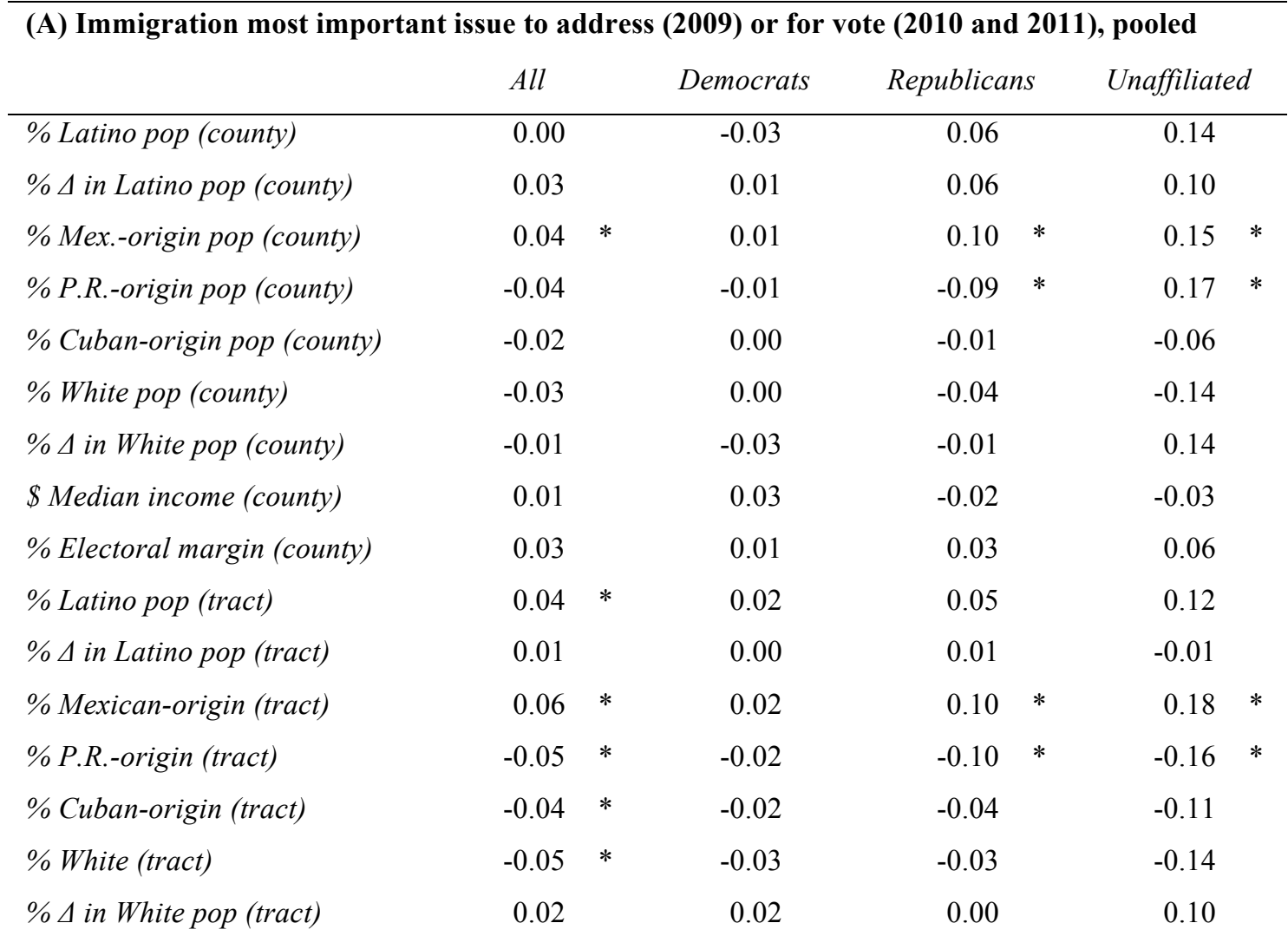

(B) Immigration most important issue facing Latino community (2011 and 2012), pooled

\begin{tabular}{|c|c|c|c|c|c|c|c|c|}
\hline & All & & Democrat & & Republica & & \multicolumn{2}{|c|}{ Unaffiliated } \\
\hline$\%$ Latino pop (county) & -0.07 & $*$ & -0.08 & * & -0.06 & * & -0.02 & \\
\hline$\% \Delta$ in Latino pop (county) & -0.07 & $*$ & -0.10 & $*$ & -0.02 & & -0.02 & \\
\hline$\%$ Mex.-origin pop (county) & 0.03 & $*$ & -0.02 & & 0.12 & $*$ & 0.06 & \\
\hline$\%$ P.R.-origin pop (county) & -0.03 & $*$ & -0.03 & $*$ & -0.04 & & -0.09 & $*$ \\
\hline$\%$ Cuban-origin pop (county) & -0.03 & $*$ & 0.04 & $*$ & -0.09 & $*$ & -0.06 & \\
\hline$\%$ White pop (county) & 0.05 & $*$ & 0.04 & * & 0.06 & * & 0.02 & \\
\hline$\% \Delta$ in White pop (county) & -0.02 & & 0.01 & & -0.06 & * & -0.03 & \\
\hline$\$$ Median income (county) & 0.06 & $*$ & 0.08 & $*$ & 0.00 & & 0.06 & \\
\hline$\%$ Electoral margin (county) & -0.01 & & -0.02 & & 0.00 & & 0.00 & \\
\hline$\%$ Latino pop (tract) & -0.06 & $*$ & -0.07 & $*$ & -0.05 & & -0.03 & \\
\hline$\% \Delta$ in Latino pop (tract) & -0.02 & & -0.03 & $*$ & -0.03 & & 0.03 & \\
\hline$\%$ Mexican-origin (tract) & 0.03 & $*$ & -0.02 & & 0.12 & $*$ & 0.05 & \\
\hline$\%$ P.R.-origin (tract) & -0.03 & $*$ & -0.04 & $*$ & -0.02 & & -0.09 & $*$ \\
\hline$\%$ Cuban-origin (tract) & -0.04 & $*$ & 0.04 & $*$ & -0.10 & $*$ & -0.04 & \\
\hline
\end{tabular}


Latino Issue Priorities and Political Behavior Across U.S. Contexts

\begin{tabular}{llllll}
$\%$ White (tract) & $0.04 *$ & $0.05 *$ & 0.04 & 0.01 \\
$\% \Delta$ in White pop (tract) & 0.00 & 0.01 & -0.01 & 0.01 \\
\hline
\end{tabular}

$* \mathrm{p}<0.05$. 
Table 2. Individual Determinants of Immigration Issue Salience

\begin{tabular}{|c|c|c|c|c|}
\hline \multirow[b]{2}{*}{ Variable } & \multicolumn{2}{|c|}{ (1) 2009-2011 } & \multicolumn{2}{|c|}{ (2) 2011-2012 } \\
\hline & Coeff. & Std. Err. & Coeff. & Std. Err. \\
\hline Republican & -0.349 & $(0.214)$ & -0.410 & $(0.142)^{* * *}$ \\
\hline Independent & -0.022 & $(0.340)$ & -0.299 & $(0.240)$ \\
\hline Non-partisan & -0.529 & $(0.523)$ & 0.132 & $(0.273)$ \\
\hline Foreign born & 1.074 & $(0.329)^{* * *}$ & 0.437 & $(0.176)^{* *}$ \\
\hline 2nd generation & 1.196 & $(0.305)^{* * *}$ & 0.312 & $(0.170)^{*}$ \\
\hline Nat origin: $P R$ & -0.541 & $(0.314)^{*}$ & -0.510 & $(0.241)^{* *}$ \\
\hline Nat origin: Cuba & -0.419 & $(0.417)$ & -0.308 & $(0.269)$ \\
\hline Nat origin: Spain & 0.024 & $(0.393)$ & -0.568 & $(0.270)^{* *}$ \\
\hline Nat origin: other & -0.290 & $(0.191)$ & 0.093 & $(0.127)$ \\
\hline Educ: high school grad & -0.075 & $(0.228)$ & -0.085 & $(0.182)$ \\
\hline Educ: some college & -0.171 & $(0.236)$ & 0.054 & $(0.193)$ \\
\hline Educ: B.A. or post-grad & 0.001 & $(0.265)$ & 0.157 & $(0.192)$ \\
\hline Educ: refused / NA & 0.849 & $(0.526)$ & -0.623 & $(0.498)$ \\
\hline Income: $\$ 20-40 \mathrm{k}$ & -0.137 & $(0.200)$ & 0.078 & $(0.170)$ \\
\hline Income: $\$ 40-80 \mathrm{k}$ & -0.680 & $(0.244)^{* * *}$ & 0.108 & $(0.173)$ \\
\hline Income: above $\$ 80 \mathrm{k}$ & -0.694 & $(0.290)^{* *}$ & 0.045 & $(0.195)$ \\
\hline Income: refused / NA & -0.484 & $(0.228)^{* *}$ & -0.079 & $(0.176)$ \\
\hline Age (years) & 0.000 & $(0.000)$ & -0.014 & $(0.003)^{* * *}$ \\
\hline Gender (female) & -0.022 & $(0.153)$ & -0.054 & $(0.106)$ \\
\hline Survey language: English & -0.745 & $(0.223)^{* * *}$ & -0.187 & $(0.138)$ \\
\hline Region: Midwest & 0.486 & $(0.305)$ & -0.154 & $(0.235)$ \\
\hline Region: Northeast & -0.270 & $(0.250)$ & -0.413 & $(0.212)^{*}$ \\
\hline Region: South & -0.292 & $(0.180)$ & 0.096 & $(0.121)$ \\
\hline Years Obama president & 0.021 & $(0.096)$ & -0.444 & $(0.115)^{* * *}$ \\
\hline (Intercept) & -1.773 & $(0.382)^{* * *}$ & 0.692 & $(0.478)$ \\
\hline $\mathrm{N}$ & \multicolumn{2}{|c|}{2058} & \multicolumn{2}{|c|}{6135} \\
\hline Pseudo $\mathrm{R}^{2}$ & \multicolumn{2}{|c|}{0.085} & \multicolumn{2}{|c|}{0.037} \\
\hline
\end{tabular}

$* \mathrm{p}<0.1 ; * * \mathrm{p}<0.05 ; * * * \mathrm{p}<0.01$. 


\section{Latino Issue Priorities and Political Behavior Across U.S. Contexts}

Table 3. County Contextual Determinants of Immigration Issue Salience

\begin{tabular}{|c|c|c|c|c|}
\hline & $\begin{array}{c}\text { (1) } \\
2009-2011\end{array}$ & $\begin{array}{c}\text { (2) } \\
2009-2011\end{array}$ & $\begin{array}{c}\text { (3) } \\
2011-2012\end{array}$ & $\begin{array}{c}\text { (4) } \\
2011-2012\end{array}$ \\
\hline Variable & $\begin{array}{c}\text { Coeff. } \\
\text { (Std. Err.) }\end{array}$ & $\begin{array}{c}\text { Coeff. } \\
\text { (Std. Err.) }\end{array}$ & $\begin{array}{c}\text { Coeff. } \\
\text { (Std. Err.) }\end{array}$ & $\begin{array}{c}\text { Coeff. } \\
\text { (Std. Err.) }\end{array}$ \\
\hline \multirow[t]{2}{*}{ Years Obama president } & 0.020 & 0.018 & -0.454 & -0.446 \\
\hline & $(0.098)$ & $(0.098)$ & $(0.117)^{* * *}$ & $(0.118) * * *$ \\
\hline \multirow[t]{2}{*}{ Population 2010 (county) } & -0.000 & -0.000 & 0.000 & 0.000 \\
\hline & $(0.000)$ & $(0.000)$ & $(0.000)$ & $(0.000)$ \\
\hline \multirow[t]{2}{*}{ \% Latino 2010 (county) } & -2.707 & -2.708 & -1.531 & -1.547 \\
\hline & $(0.992) * * *$ & $(0.998) * * *$ & $(0.699)^{* *}$ & $(0.691)^{* *}$ \\
\hline \multirow[t]{2}{*}{$\% \Delta$ Latino $00-10$ (county) } & 1.214 & 1.212 & 0.851 & 0.903 \\
\hline & $(1.413)$ & $(1.437)$ & $(0.885)$ & $(0.874)$ \\
\hline \multirow[t]{2}{*}{ \% Mexican 2010 (county) } & 0.131 & 0.103 & -0.459 & -0.425 \\
\hline & $(0.805)$ & $(0.804)$ & $(0.462)$ & $(0.464)$ \\
\hline \multirow[t]{2}{*}{ \% Puerto Rican 2010 (county) } & -0.444 & -0.481 & -1.307 & -1.319 \\
\hline & $(1.089)$ & $(1.086)$ & $(0.716)^{*}$ & $(0.718)^{*}$ \\
\hline \multirow[t]{2}{*}{ \% Cuban 2010 (county) } & 0.868 & 0.901 & -0.218 & -0.299 \\
\hline & $(1.476)$ & $(1.477)$ & $(0.813)$ & $(0.812)$ \\
\hline \multirow[t]{2}{*}{$\%$ Non-Latino white 2010 (county) } & -1.085 & -0.929 & 0.117 & -0.020 \\
\hline & $(1.182)$ & $(1.236)$ & $(0.860)$ & $(0.855)$ \\
\hline \multirow[t]{2}{*}{$\% \Delta$ Non-Latino white $00-10$ (county) } & 0.428 & 0.473 & 0.247 & 0.293 \\
\hline & $(1.428)$ & $(1.456)$ & $(1.156)$ & $(1.129)$ \\
\hline \multirow[t]{2}{*}{ Log Median hh income 2010 (county) } & -0.344 & -0.371 & -0.209 & -0.212 \\
\hline & $(0.485)$ & $(0.487)$ & $(0.337)$ & $(0.335)$ \\
\hline \multirow[t]{2}{*}{ Border state } & 0.309 & 0.299 & 0.072 & 0.095 \\
\hline & $(0.340)$ & $(0.340)$ & $(0.177)$ & $(0.177)$ \\
\hline \multirow[t]{2}{*}{ Competitive (county) } & 0.247 & -0.018 & -0.024 & 0.337 \\
\hline & $(0.192)$ & $(0.425)$ & $(0.130)$ & $(0.273)$ \\
\hline \multirow[t]{2}{*}{ \% Latino 2010 (county) x Comp. (county) } & & 0.723 & & -1.023 \\
\hline & & $(1.046)$ & & $(0.698)$ \\
\hline \multirow[t]{2}{*}{ (Intercept) } & 1.671 & 1.847 & 2.849 & 2.798 \\
\hline & $(5.399)$ & $(5.423)$ & $(3.714)$ & $(3.696)$ \\
\hline Individual controls & $\mathrm{Y}$ & $\mathrm{Y}$ & $\mathrm{Y}$ & $\mathrm{Y}$ \\
\hline $\mathrm{N}$ & 2058 & 2058 & 6135 & 6135 \\
\hline Pseudo $\mathrm{R}^{2}$ & 0.094 & 0.094 & 0.045 & 0.046 \\
\hline
\end{tabular}

\footnotetext{
$* \mathrm{p}<0.1 ; * * \mathrm{p}<0.05 ; * * * \mathrm{p}<0.01$
} 


\section{Latino Issue Priorities and Political Behavior Across U.S. Contexts}

Table 4. Neighborhood Contextual Determinants of Immigration Issue Salience

\begin{tabular}{|c|c|c|c|c|}
\hline & $\begin{array}{c}\text { (1) } \\
2009-2011\end{array}$ & $\begin{array}{c}\text { (2) } \\
2009-2011\end{array}$ & $\begin{array}{c}\text { (3) } \\
2011-2012\end{array}$ & $\begin{array}{c}\text { (4) } \\
2011-2012\end{array}$ \\
\hline Variable & $\begin{array}{c}\text { Coeff. } \\
\text { (Std. Err.) }\end{array}$ & $\begin{array}{c}\text { Coeff. } \\
\text { (Std. Err.) }\end{array}$ & $\begin{array}{c}\text { Coeff. } \\
\text { (Std. Err.) }\end{array}$ & $\begin{array}{c}\text { Coeff. } \\
\text { (Std. Err.) }\end{array}$ \\
\hline Years Obama president & $\begin{array}{c}0.017 \\
(0.097)\end{array}$ & $\begin{array}{c}0.023 \\
(0.098)\end{array}$ & $\begin{array}{c}-0.483 \\
(0.115) * * *\end{array}$ & $\begin{array}{c}-0.477 \\
(0.115) * * *\end{array}$ \\
\hline Population 2010 (tract) & $\begin{array}{l}-0.000 \\
(0.000)\end{array}$ & $\begin{array}{l}-0.000 \\
(0.000)\end{array}$ & $\begin{array}{c}0.000 \\
(0.000)\end{array}$ & $\begin{array}{c}0.000 \\
(0.000)\end{array}$ \\
\hline \% Latino 2010 (tract) & $\begin{array}{l}-0.533 \\
(0.528)\end{array}$ & $\begin{array}{l}-0.719 \\
(0.530)\end{array}$ & $\begin{array}{c}-0.808 \\
(0.413)^{*}\end{array}$ & $\begin{array}{c}-0.706 \\
(0.420)^{*}\end{array}$ \\
\hline$\% \Delta$ Latino $00-10$ (tract) & $\begin{array}{l}-0.225 \\
(0.364)\end{array}$ & $\begin{array}{l}-0.254 \\
(0.360)\end{array}$ & $\begin{array}{l}-0.372 \\
(0.244)\end{array}$ & $\begin{array}{l}-0.382 \\
(0.242)\end{array}$ \\
\hline \% Mexican 2010 (tract) & $\begin{array}{l}-0.239 \\
(0.555)\end{array}$ & $\begin{array}{l}-0.229 \\
(0.557)\end{array}$ & $\begin{array}{l}-0.357 \\
(0.375)\end{array}$ & $\begin{array}{l}-0.361 \\
(0.374)\end{array}$ \\
\hline \% Puerto Rican 2010 (tract) & $\begin{array}{l}-0.973 \\
(0.721)\end{array}$ & $\begin{array}{l}-1.019 \\
(0.723)\end{array}$ & $\begin{array}{c}-1.022 \\
(0.620)^{*}\end{array}$ & $\begin{array}{c}-1.036 \\
(0.621)^{*}\end{array}$ \\
\hline$\%$ Cuban 2010 (tract) & $\begin{array}{l}-0.368 \\
(1.019)\end{array}$ & $\begin{array}{l}-0.265 \\
(1.020)\end{array}$ & $\begin{array}{l}-0.143 \\
(0.609)\end{array}$ & $\begin{array}{l}-0.201 \\
(0.610)\end{array}$ \\
\hline$\%$ Non-Latino white 2010 (tract) & $\begin{array}{l}-0.182 \\
(0.526)\end{array}$ & $\begin{array}{l}-0.093 \\
(0.528)\end{array}$ & $\begin{array}{l}-0.397 \\
(0.414)\end{array}$ & $\begin{array}{l}-0.425 \\
(0.412)\end{array}$ \\
\hline$\% \Delta$ Non-Latino white $00-10$ (tract) & $\begin{array}{l}-0.003 \\
(0.148)\end{array}$ & $\begin{array}{c}0.001 \\
(0.150)\end{array}$ & $\begin{array}{c}0.023 \\
(0.114)\end{array}$ & $\begin{array}{c}0.017 \\
(0.114)\end{array}$ \\
\hline Log Median hh income 2010 (county) & $\begin{array}{c}0.094 \\
(0.398)\end{array}$ & $\begin{array}{c}0.004 \\
(0.401)\end{array}$ & $\begin{array}{c}0.156 \\
(0.278)\end{array}$ & $\begin{array}{c}0.178 \\
(0.277)\end{array}$ \\
\hline Border state & $\begin{array}{c}0.278 \\
(0.338)\end{array}$ & $\begin{array}{c}0.289 \\
(0.340)\end{array}$ & $\begin{array}{c}0.073 \\
(0.166)\end{array}$ & $\begin{array}{r}0.075 \\
(0.167)\end{array}$ \\
\hline Competitive (county) & $\begin{array}{c}0.206 \\
(0.185)\end{array}$ & $\begin{array}{l}-0.418 \\
(0.358)\end{array}$ & $\begin{array}{l}-0.097 \\
(0.127)\end{array}$ & $\begin{array}{c}0.161 \\
(0.225)\end{array}$ \\
\hline \% Latino 2010 (tract) x Comp. (county) & & $\begin{array}{c}1.263 \\
(0.634)^{* *}\end{array}$ & & $\begin{array}{l}-0.632 \\
(0.475)\end{array}$ \\
\hline (Intercept) & $\begin{array}{l}-2.147 \\
(4.398)\end{array}$ & $\begin{array}{l}-1.109 \\
(4.439)\end{array}$ & $\begin{array}{c}0.326 \\
(3.200)\end{array}$ & $\begin{array}{c}0.067 \\
(3.196)\end{array}$ \\
\hline Individual controls & $\mathrm{Y}$ & $\mathrm{Y}$ & $\mathrm{Y}$ & $\mathrm{Y}$ \\
\hline $\mathrm{N}$ & 2056 & 2056 & 6129 & 6129 \\
\hline Pseudo $\mathrm{R}^{2}$ & 0.090 & 0.093 & 0.044 & 0.045 \\
\hline
\end{tabular}

$* \mathrm{p}<0.1 ; * * \mathrm{p}<0.05 ; * * * \mathrm{p}<0.01$ 


\section{Latino Issue Priorities and Political Behavior Across U.S. Contexts}

Table 5. Predicting Latino Party Identification and Vote Choice with Issue Salience

\begin{tabular}{|c|c|c|c|c|c|c|}
\hline \multirow[b]{3}{*}{ Variable } & \multicolumn{3}{|c|}{ DV = Democratic PID } & \multicolumn{3}{|c|}{ DV = Vote for BO vs. MR } \\
\hline & All & Border & $\begin{array}{l}\text { Non- } \\
\text { Border }\end{array}$ & All & Border & $\begin{array}{c}\text { Non- } \\
\text { Border }\end{array}$ \\
\hline & $\begin{array}{c}\text { Coeff. } \\
\text { (Std. Err.) }\end{array}$ & $\begin{array}{c}\text { Coeff. } \\
\text { (Std. Err.) }\end{array}$ & $\begin{array}{c}\text { Coeff. } \\
\text { (Std. Err.) }\end{array}$ & $\begin{array}{c}\text { Coeff. } \\
\text { (Std. Err.) }\end{array}$ & $\begin{array}{c}\text { Coeff. } \\
\text { (Std. Err.) }\end{array}$ & $\begin{array}{c}\text { Coeff. } \\
\text { (Std. Err.) }\end{array}$ \\
\hline Issue: Immigration & $\begin{array}{c}0.559 \\
(0.155)^{* * *}\end{array}$ & $\begin{array}{c}0.695 \\
(0.178)^{* * *}\end{array}$ & $\begin{array}{c}0.312 \\
(0.305)\end{array}$ & $\begin{array}{c}0.417 \\
(0.140)^{* * *}\end{array}$ & $\begin{array}{c}0.529 \\
(0.161)^{* * *}\end{array}$ & $\begin{array}{c}0.109 \\
(0.279)\end{array}$ \\
\hline Issue: Education & $\begin{array}{c}1.262 \\
(0.220)^{* * *}\end{array}$ & $\begin{array}{c}1.421 \\
(0.248)^{* * *}\end{array}$ & $\begin{array}{c}0.908 \\
(0.488)^{*}\end{array}$ & $\begin{array}{c}1.140 \\
(0.188)^{* * * *}\end{array}$ & $\begin{array}{c}1.206 \\
(0.212)^{* * *}\end{array}$ & $\begin{array}{c}0.898 \\
(0.414)^{* *}\end{array}$ \\
\hline Issue: Health & $\begin{array}{c}1.209 \\
(0.252)^{* * *}\end{array}$ & $\begin{array}{c}1.206 \\
(0.289)^{* * *}\end{array}$ & $\begin{array}{c}1.198 \\
(0.483)^{* *}\end{array}$ & $\begin{array}{c}0.933 \\
(0.212)^{* * *}\end{array}$ & $\begin{array}{c}0.801 \\
(0.243)^{* * *}\end{array}$ & $\begin{array}{c}1.172 \\
(0.439)^{* * * *}\end{array}$ \\
\hline Issue: Economy & $\begin{array}{c}0.008 \\
(0.135)\end{array}$ & $\begin{array}{l}-0.009 \\
(0.153)\end{array}$ & $\begin{array}{c}0.116 \\
(0.269)\end{array}$ & $\begin{array}{c}0.117 \\
(0.125)\end{array}$ & $\begin{array}{c}0.092 \\
(0.144)\end{array}$ & $\begin{array}{c}0.183 \\
(0.242)\end{array}$ \\
\hline (Intercept) & $\begin{array}{l}-5.006 \\
(3.584)\end{array}$ & $\begin{array}{l}-2.320 \\
(4.901)\end{array}$ & $\begin{array}{c}-15.812 \\
(7.292)^{* *}\end{array}$ & $\begin{array}{l}-0.177 \\
(3.357)\end{array}$ & $\begin{array}{l}-5.382 \\
(4.752)\end{array}$ & $\begin{array}{c}2.104 \\
(7.276)\end{array}$ \\
\hline Individual controls & $\mathrm{Y}$ & $\mathrm{Y}$ & $\mathrm{Y}$ & $\mathrm{Y}$ & $\mathrm{Y}$ & $\mathrm{Y}$ \\
\hline Contextual controls & $\mathrm{Y}$ & $\mathrm{Y}$ & $\mathrm{Y}$ & Y & Y & $\mathrm{Y}$ \\
\hline $\mathrm{N}$ & 6131 & 3272 & 2859 & 6131 & 3272 & 2859 \\
\hline Pseudo $\mathrm{R}^{2}$ & 0.113 & 0.116 & 0.149 & 0.082 & 0.077 & 0.123 \\
\hline
\end{tabular}

$* \mathrm{p}<0.1 ; * * \mathrm{p}<0.05 ; * * * \mathrm{p}<0.01$ 
Latino Issue Priorities and Political Behavior Across U.S. Contexts

Table 6. Changes in Predicted Probabilities of Latino Party Identification and Vote Choice

\begin{tabular}{lccc} 
DV = Democratic PID & & & \\
\hline & \multicolumn{1}{c}{$\Delta$} & \multicolumn{1}{c}{ Std. } & \\
& $\operatorname{Pr}(y=1)$ & $E r r$. & \\
\cline { 2 - 4 } All Latinos & 0.117 & $(0.034)$ & $* *$ \\
Border State & 0.154 & $(0.042)$ & $* *$ \\
Non-Border & 0.053 & $(0.055)$ & \\
& & & \\
DV = Obama vote choice & & & \\
\hline & \multicolumn{1}{c}{$\Delta$} & $S t d$. & \\
& $\operatorname{Pr}(y=1)$ & $E r r$. & \\
\cline { 2 - 5 } All Latinos & 0.100 & $(0.034)$ & $* *$ \\
Border State & 0.129 & $(0.040)$ & $* *$ \\
Non-Border & 0.024 & $(0.063)$ & \\
\hline
\end{tabular}

$* \mathrm{p}<0.05 ; * * \mathrm{p}<0.01$ 